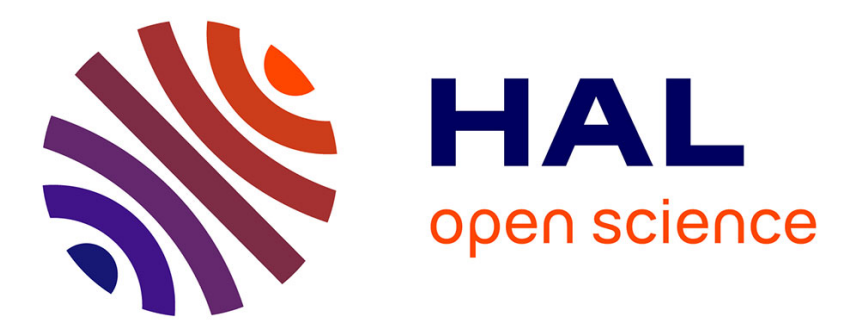

\title{
ON THE ROLE OF CARBON DIOXIDE IN THE COMBUSTION OF ALUMINUM DROPLETS
}

Vincent Sarou-Kanian, Jean-Claude Rifflet, Francis Millot, Emmanuel Véron, Thierry Sauvage, Iskender Gökalp

\section{- To cite this version:}

Vincent Sarou-Kanian, Jean-Claude Rifflet, Francis Millot, Emmanuel Véron, Thierry Sauvage, et al.. ON THE ROLE OF CARBON DIOXIDE IN THE COMBUSTION OF ALUMINUM DROPLETS. Combustion Science and Technology, 2005, 177 (12), pp.2299-2326. 10.1080/00102200500241107. hal-00429418

\section{HAL Id: hal-00429418 https://hal.science/hal-00429418}

Submitted on 2 Dec 2021

HAL is a multi-disciplinary open access archive for the deposit and dissemination of scientific research documents, whether they are published or not. The documents may come from teaching and research institutions in France or abroad, or from public or private research centers.
L'archive ouverte pluridisciplinaire HAL, est destinée au dépôt et à la diffusion de documents scientifiques de niveau recherche, publiés ou non, émanant des établissements d'enseignement et de recherche français ou étrangers, des laboratoires publics ou privés. 


\section{On the Role of Carbon Dioxide in the Combustion of Aluminum Droplets}

V. SAROU-KANIAN ${ }^{\mathrm{a}, \mathrm{b}}$, J.C. RIFFLET ${ }^{\mathrm{a}}$, F. MILLOT ${ }^{\mathrm{a}}$, E. VERON ${ }^{\mathrm{a}}$, T. SAUVAGE ${ }^{\mathrm{c}}$ and I. GÖKALP ${ }^{b}$

${ }^{a}$ Centre de Recherches sur les Matériaux à Haute Température, CNRS, 1D av. de la Recherche Scientifique 45071 Orléans Cedex $2 ;^{b}$ Laboratoire de Combustion et Systèmes Réactifs, CNRS, 1C av. de la Recherche Scientifique 45071 Orléans Cedex 2; ${ }^{\mathrm{c}}$ Centre d'Etudes et de Recherches par Irradiation, CNRS, 3A rue de la Férollerie 45071 Orléans Cedex 2 . 


\section{ABSTRACT}

In this paper, the influence of carbon dioxide on the combustion of aluminum droplets is investigated. Millimeter sized droplets were heated and ignited by a laser in an aerodynamic levitation system in several $\mathrm{CO}_{2}$ containing atmospheres $\left(\mathrm{H}_{2} \mathrm{O} / \mathrm{CO}_{2}, \mathrm{H}_{2} \mathrm{O} / \mathrm{CO}_{2} / \mathrm{N}_{2}\right)$ with a large range of compositions (wet $-\mathrm{x}_{\mathrm{H} 2 \mathrm{O}}<3 \%, 80 / 20,50 / 50,12.5 / 87.5,50 / 25 / 25,20 / 40 / 40$ ). The combustion processes were observed with a high-speed CCD camera and the droplet radiation was recorded by two optical pyrometers. The ignition occurs with the oxide coating breakdown which liquefies to form an initial cap moving on the droplet surface. Aluminum vaporizes and burns with the oxidizers as a detached diffusion flame. The droplet regression rate, i.e. the burning rate, strongly depends on the oxidizing atmosphere, from $\beta=0.58 \mathrm{~mm}^{2} / \mathrm{s}$ in wet $50 \% \mathrm{CO}_{2} / 50 \% \mathrm{~N}_{2}$ to $\beta=2.45 \mathrm{~mm}^{2} / \mathrm{s}$ in $80 \% \mathrm{H}_{2} \mathrm{O} / 20 \% \mathrm{CO}_{2}$. It is shown that $\mathrm{CO}_{2}$ is the worst oxidizer with a smaller "oxidizer efficiency" $e_{\mathrm{CO}_{2}}=(0.18 \pm 0.02)$ compared to $\mathrm{H}_{2} \mathrm{O}$ $\left(e_{\mathrm{H} 2 \mathrm{O}}=0.48 \pm 0.05\right)$ and $\mathrm{O}_{2}\left(e_{O 2}=1\right)$. The burning droplet temperature in wet $\mathrm{CO}_{2}$ and in the $\mathrm{H}_{2} \mathrm{O} / \mathrm{CO}_{2}$ mixtures is around $\mathrm{T} \approx 2600 \mathrm{~K}$, and is smaller in $\mathrm{H}_{2} \mathrm{O} / \mathrm{CO}_{2} / \mathrm{N}_{2}(\mathrm{~T} \approx 2450 \mathrm{~K})$. The noncorrelation between the burning rates and the droplet temperatures confirms that the combustion processes are limited by molecular diffusion, and highlights the influence of $\mathrm{H}_{2}$ in the gas-phase transport. An estimation of the exponent $n$ of the "d ${ }^{n}$ law" shows that $n$ decreases with the increase of $\mathrm{CO}_{2}$ from $n=1.7$ to $n=0.6$. The stagnant burning rates are evaluated as being 7 to 9 times smaller than the measured ones with convective effects. Furthermore, during the droplet regression, the oxide cap dimensions also regress and it is generally completely removed. Oxide cap regression rates are estimated and are slower than their respective burning rates. Nevertheless, there is a good correlation between the oxide cap regression rate and the droplet temperature which shows that the oxide cap regression results from the chemical decomposition of $\mathrm{Al}_{2} \mathrm{O}_{3}$ by the liquid $\mathrm{Al}$ droplet producing gaseous $\mathrm{Al}_{\mathrm{x}} \mathrm{O}_{\mathrm{y}}$. For $\mathrm{CO}_{2}$ concentration higher than $40 \%$, a solid phase suddenly appears on the liquid $\mathrm{Al}$ 
surface which entirely covers the droplet leading to the end of the gas-phase combustion. This phenomenon is the consequence of the massive dissolution of carbon in the droplet during burning. Analyses of the unburnt residues showed amounts of dissolved carbon up to $20-23 \%$ molar which is near the saturation concentration limit. Thus, the solid coating corresponds to the ejection of carbon from the droplet because of its continuing regression, and is expected to be also present for smaller particles. Therefore, carbon dioxide plays a double role. First, it participates to the gas-phase combustion but it is the worse oxidizer with smaller burning rates. Second, $\mathrm{CO}_{2}$ causes the carbon dissolution in the $\mathrm{Al}$ droplet and finally stops the gasphase burning. A further implication could be that carbon dioxide may promote the appearance of a combustion regime with surface reactions only.

Keywords: aluminum, droplet, combustion, carbon dioxide, dissolution, convection.

Short running title: $\mathrm{CO}_{2}$ effects on aluminum droplet combustion 


\section{INTRODUCTION}

Aluminum is known to be one of the best energetic metal, and for this reason, it has been used in solid rocket motors. Submillimetric aluminum powders are generally added in an ammonium perchlorate-binder mixture which increases the specific impulse of the solid propellant. During the propellant decomposition, single aluminum particles or agglomerates are ejected from the surface and burn in the gaseous atmosphere which is essentially composed of $\mathrm{H}_{2} \mathrm{O}, \mathrm{CO}_{2}, \mathrm{HCl}, \mathrm{N}_{2}, \mathrm{H}_{2}, \mathrm{CO}$. The understanding of the combustion of aluminum particle in $\mathrm{CO}_{2}$ atmospheres is very important because it represents one of the main oxidizers with $\mathrm{H}_{2} \mathrm{O}$. Furthermore, there is a renewal of interest for the combustion of metals in carbon dioxide related with the recent projects of explorations of Mars. Indeed, the Martian soil containing a significant proportion of $\mathrm{Al}, \mathrm{Mg}, \mathrm{Si}$ and $\mathrm{Fe}$ and its atmosphere being composed of $95 \% \mathrm{CO}_{2}$, propulsion systems using these two natural resources have been proposed for the return on Earth.

Several studies have been performed since several decades on the combustion of aluminum particles in pure $\mathrm{CO}_{2}$ or in $\mathrm{CO}_{2}$ containing mixtures giving the following observations. First, the $\mathrm{Al}$ burning in $\mathrm{CO}_{2}$ mainly takes place in the gas-phase with the formation of a diffusion flame (Mellor and Glassman, 1964; Yuasa et al., 1992; Bucher et al., 1999; Legrand et al., 2001) like under $\mathrm{O}_{2}$ and $\mathrm{H}_{2} \mathrm{O}$. Second, $\mathrm{CO}_{2}$ is probably the less efficient oxidizer compared to $\mathrm{O}_{2}$ and $\mathrm{H}_{2} \mathrm{O}$ in terms of burning times or burning rates (Davis, 1963; Olsen and Beckstead, 1995; Marion, 1996; Bucher et al., 1999; Legrand, 2000). Furthermore, it was pointed out that it could be more difficult to ignite the $\mathrm{Al}$ particle in pure $\mathrm{CO}_{2}$ (Ernst et al., 2000; Legrand et al., 2001) and that the combustion could be incomplete (Prentice, 1974; Zenin et al., 2001). Finally, the recent work of Rossi et al. (2001) have introduced one of the most interesting fact with the evidence of a massive carbon dissolution in the particle (up to $20 \%$ mol C) during combustion in pure $\mathrm{CO}_{2}$. This observation agrees with those made by Dreizin $(1996,1999)$ 
for $\mathrm{O}_{2}$ mixtures and Sarou-Kanian et al. (2004) on the influence of $\mathrm{N}_{2}$, in the sense that heterogeneous reactions at the $\mathrm{Al}$ surface and in the bulk play an important role in the combustion processes.

In the present work, we propose to investigate the combustion of aluminum droplets in several $\mathrm{CO}_{2}$ containing atmospheres in order to quantify precisely the role of carbon dioxide both in the gas-phase processes (burning rates) and in the heterogeneous ones (dissolution, oxide cap). Thus we used an experimental setup allowing to observe very clearly both the regression of millimetric Al burning droplets and the phenomena occurring at the surface. Then we analyzed the interior of the unburnt residues in order to confirm the presence of dissolved carbon.

\section{EXPERIMENTAL}

The experimental setup is based on an improved technique which has been developed for several years to study thermophysical properties of liquid metal or oxide at high temperatures (Glorieux et al., 1999, 2002; Wille et al., 2002; Sarou-Kanian et al., 2003). A millimetric spherical-shaped sample is maintained contactless in an aerodynamic levitator and is heated by a continuous $\mathrm{CO}_{2}$ laser (Coherent Everlase $525 ; \lambda=10.6 \mu \mathrm{m} ; \mathrm{P}=30-800 \mathrm{~W}$ ). The levitation gases are in fact the gaseous reactants which allows to examine a large range of $\mathrm{CO}_{2}$ containing atmospheres such as wet $\mathrm{CO}_{2}$, and $\mathrm{H}_{2} \mathrm{O} / \mathrm{CO}_{2}$, wet $\mathrm{CO}_{2} / \mathrm{N}_{2}$, and $\mathrm{H}_{2} \mathrm{O} / \mathrm{CO}_{2} / \mathrm{N}_{2}$ mixtures with variable compositions $(80 / 20,50 / 50,20 / 80,12.5 / 87.5,50 / 25 / 25,20 / 40 / 40)$. The water steam is produced in a boiler and transported through an overheated column up to the levitation system in order to avoid condensation. The water-based mixtures are obtained by fixing the boiler temperature $\left(\mathrm{P}_{\mathrm{H} 2 \mathrm{O}}=\mathrm{f}\left(\mathrm{T}_{\text {boiler }}\right)\right)$ and the total pressure $\left(\mathrm{P}_{\mathrm{T}}=\mathrm{P}_{\mathrm{H} 2 \mathrm{O}}+\mathrm{P}_{\mathrm{CO} 2, \mathrm{~N} 2}\right)$; wet atmospheres correspond to $\mathrm{T}_{\text {boiler }}=\mathrm{T}_{\text {ambient }}$, that is $\mathrm{x}_{\mathrm{H} 20}<3 \%$. Silver made nozzle guarantees no 
oxidation, a good quality of reflection of the laser beam $\left(\Phi_{\text {beam }}=13 \mathrm{~mm}>\mathrm{d}_{\text {droplet }} \approx 3 \mathrm{~mm}\right)$ and an excellent thermal conduction (fast sample quenching).

Ignition and combustion processes are observed with a high-speed CCD camera Kodak EktaPro 1000HRColor (512×384 pixel resolution, 8-bit coding, $1000 \mathrm{~Hz}$ maxi speed, exposure $50 \mu \mathrm{s}-4 \mathrm{~ms}, 5460$ recorded frames maxi). The magnification of the optical system (Berthiot telephoto lens, $\mathrm{f}=145 \mathrm{~mm}$, aperture 1:4.5) is about 1 .

The light emitted from the droplet is detected by two optical pyrometers $(\lambda \approx 0.8 \mu \mathrm{m})$. One of them (Pyritron PE3) is focused on the top of the droplet, and the other (Ircon 1250C) on the bottom of it through the levitation nozzle hole. The top pyrometer was only used for the temperature measurements before ignition. Indeed, it was impossible to process the signal during combustion because of the smokes composed of very emissive/absorptive alumina particles which were ejected in the wake of the flame by the levitation gas flow and which cross the field of view of the pyrometer. On the contrary, the bottom pyrometer always detected the thermal radiation mainly from the Al droplet surface whatever the processes (ignition or combustion). The pyrometric signals are transferred to a computer with an interfacing PCI card (12-bit coding, $500 \mathrm{~Hz}$ for each channel) which also controls the laser shut-off at ignition or during the combustion. The camera is also equipped with the Kodak Multi-Channel Data Link to insert the pyrometric signals and laser shut-off in each frame.

Samples were prepared from aluminum foils (Merck with a $99.95 \%$ purity), melted and transformed into droplets in the levitation set-up under argon atmosphere to avoid oxidation. Droplet sizes are about $2.5-3 \mathrm{~mm}$ in diameter $(25-40 \mathrm{mg})$. For each studied atmosphere, at least two experiments were performed to confirm the significance of the results (more than ten tests for some ones, about fifty tests on the whole).

Unburnt residues were observed with an optical microscope (cross-sections) and a scanning electron microscope (Philips ESEM XL40 TMP - global views and cross-sections). Some of 
them cooled slowly (no impact on the levitator) produced crystallized phases which were analyzed by X-ray diffraction (grinded samples). The interior of fast quenched residues (polished cross-sections) was analyzed by Electron Dispersive Spectroscopy (EDS). A global carbon analysis was also carried out for some residues by nuclear activation using the facilities of the CERI ${ }^{\mathrm{c}}$ (Sarou-Kanian, 2003).

\section{RESULTS}

\section{Visual observations}

In the first steps of ignition and combustion processes, the observations with the high-speed camera (Figure 1) are similar to those which were described by Sarou-Kanian et al. (2004) in $\mathrm{H}_{2} \mathrm{O} / \mathrm{O}_{2}, \mathrm{H}_{2} \mathrm{O} / \mathrm{Ar}$, or $\mathrm{H}_{2} \mathrm{O} / \mathrm{N}_{2}$ atmospheres. During the pre-ignition phase, the $\mathrm{Al}$ droplet is gradually covered by a thin solid alumina coating (Figure 1, Frame 1) which increases the heating rate with the $\mathrm{CO}_{2}$ laser (better absorption of the $10.6 \mu \mathrm{m}$ radiation of $\mathrm{Al}_{2} \mathrm{O}_{3}$ than $\mathrm{Al}$ ). The ignition occurs with the oxide coating breakdown initiated from an overheated point in the top hemisphere of the droplet (Frame 2). The oxidizers then react on the free Al surface and liquefy the solid alumina coating (Frame 3) forming several small caps (Frame 4) which finally coalesce as a single one (Frame 5). At the same time, the aluminum surface starts to vaporize, and a diffusion flame which is clearly detached from the surface sets in (Frame 5). The steady regime of combustion takes place with the regression of the droplet size but also of the oxide cap (Frames 5 to 11). At this stage, two situations can happen as a function of the $\mathrm{CO}_{2}$ concentration.

For $\mathrm{x}_{\mathrm{CO} 2}<0.4$, the combustion continues with no particular change until aerodynamic instabilities appear due to the too strong gas flow in comparison to droplet mass, and the impact on the sides of the levitator (Frame 12) marking the end of burning. 
On the contrary, for $\mathrm{x}_{\mathrm{CO} 2} \geq 0.4$, a solid phase, more luminous than liquid $\mathrm{Al}$, suddenly appears on the droplet surface and covers it entirely in few milliseconds (Figure 2, Frames 1 to 3). The vaporization of aluminum becoming impossible, the gas-phase combustion stops. The droplet begins to cool freely in the levitation gases, and some strains are visible on the surface (Frames 4 and 5). Suddenly, the droplet emits more light (Frame 6) and its surface is still strained (Frame 7). Finally, the droplet cools softly (Frame 8) or impacts on the sides of the levitation system.

A particular case concerns the combustion in wet $50 \% \mathrm{CO}_{2} / 50 \% \mathrm{~N}_{2}$. A solid phase also appears on the droplet surface, but its growth is slower (complete cover $\approx 0.8-0.9 \mathrm{~s}$ ). This phenomenon corresponds to the formation and the growth of solid aluminum nitride on the $\mathrm{Al}$ surface in $\mathrm{H}_{2} \mathrm{O} / \mathrm{N}_{2}$ observed by Sarou-Kanian et al. (2004).

\section{Luminous signals and droplet temperatures}

The light emitted from the droplet is detected with the optical pyrometer which is focused on its bottom hemisphere. Figure 3 illustrates the typical signals recorded during the combustion of aluminum droplets in different $\mathrm{CO}_{2}$ containing atmospheres. Note that $\mathrm{t}=0 \mathrm{~s}$ does not correspond to the beginning of the laser heating; the pre-heating time is generally more than $10 \mathrm{~s}$ and varies with the laser power.

First we observe that the intensity of the thermal radiation signal just before ignition is quite the same $(\mathrm{U}=1.5 \pm 0.2 \mathrm{~V})$ for all gaseous atmospheres which suggests that the ignition temperature does probably not depend on the nature and concentration of the oxidizers $\left(\mathrm{H}_{2} \mathrm{O}\right.$, $\left.\mathrm{CO}_{2}\right)$.

The situation is completely different during the combustion phase. Indeed, our experiments have shown that it was more and more uneasy for the combustion to become autonomous when $\mathrm{CO}_{2}$ was the major oxidizing species $\left(>50 \%\right.$ mol in $\mathrm{H}_{2} \mathrm{O} / \mathrm{CO}_{2}$, wet $\mathrm{CO}_{2}$, 
$20 \% \mathrm{H}_{2} \mathrm{O} / 40 \% \mathrm{CO}_{2} / 40 \% \mathrm{~N}_{2}$ ). Thus, it was necessary to keep on heating the droplet with the laser for a longer time after ignition before the combustion becomes autonomous. For the particular cases of wet $\mathrm{CO}_{2}$ and wet $50 \% \mathrm{CO}_{2} / 50 \% \mathrm{~N}_{2}$, the combustion always stopped if the laser was cut off. The laser heating effect is clearly visible on the thermal radiation signal profiles in Figure 3 (c-d-e-f-g). It also suggests that the droplet temperature with the laser contribution increases with the $\mathrm{CO}_{2}$ concentration in $\mathrm{H}_{2} \mathrm{O} / \mathrm{CO}_{2}$ atmospheres. However, we can note that when the combustion is autonomous and steady, the intensity of the signal is around the same value $\left(\mathrm{U}=3.0 \pm 0.2 \mathrm{~V}\right.$ in $\mathrm{H}_{2} \mathrm{O} / \mathrm{CO}_{2} ; \mathrm{U}=2.0 \pm 0.2 \mathrm{~V}$ in $\left.\mathrm{H}_{2} \mathrm{O} / \mathrm{CO}_{2} / \mathrm{N}_{2}\right)$. On Figure 3 (cd-e-g), we can also remark that the thermal radiation signals become unsteady at the end of burning. This event must be related to the appearance of the surface phenomena which were observed for the high $\mathrm{CO}_{2}$ concentration and described the part "Visual Observations". Figure 3 (d) shows a detail of the signal profile when these phenomena occurs with the solid phase formation first, then the slight cooling, and finally the sudden light emission.

The droplet temperature was estimated from the Wien's approximation of the second Planck's law, and the assumption that the droplet surface was a grey-body (spectral emissivity $\varepsilon_{\lambda}<1$ ). The optical pyrometers were first calibrated on the crystallization plateau of a liquid alumina droplet $\left(\mathrm{T}_{\text {calib }}=2327 \mathrm{~K}, \varepsilon_{\text {calib }}=\varepsilon_{\mathrm{Al2O} 3}\right)$ freely cooling in the same gaseous atmospheres as in the Al burning experiments. The droplet temperature was calculated as follows:

$$
\frac{1}{\mathrm{~T}}=\frac{1}{\mathrm{~T}_{\text {calib. }}}+\frac{\lambda}{\mathrm{C}_{2}} \cdot \operatorname{Ln}\left(\frac{\varepsilon_{\text {exp }}}{\varepsilon_{\text {calib. }}} \cdot \frac{\mathrm{U}_{\text {calib. }}}{\mathrm{U}_{\mathrm{Al}}}\right)
$$

Because we used two monochromatic pyrometers with the same wavelength $(\lambda \approx 0.8 \mu \mathrm{m})$, we have to fix arbitrarily the emissivity ratio $\varepsilon_{\mathrm{exp}} / \varepsilon_{\mathrm{Al} 2 \mathrm{O} 3}$. Here the choice of this parameter is very 
important because the evaluation of the droplet temperature can strongly change in this high temperature range with small variations of emissivity. Furthermore, the light which is detected by the bottom pyrometer is not only due to the emitting aluminum surface, but also to the oxide coating before ignition or to the thin flame during burning. The consequence of these additional radiations may be seen as an artificial increase of spectral emissivity such as:

$\begin{cases}\varepsilon_{\text {exp }}=\varepsilon_{\mathrm{Al}}+\varepsilon_{\text {oxide coating }} & \text { for } \mathrm{t}<\mathrm{t}_{\text {ignition }} \\ \varepsilon_{\exp }=\varepsilon_{\mathrm{Al}}+\varepsilon_{\text {flame }} & \text { for } \mathrm{t}>\mathrm{t}_{\text {igntion }}\end{cases}$

However, we can have a good estimation of $\varepsilon_{\text {exp }} / \varepsilon_{\mathrm{A} 12 \mathrm{O} 3}$ with some appropriate assumptions such as:

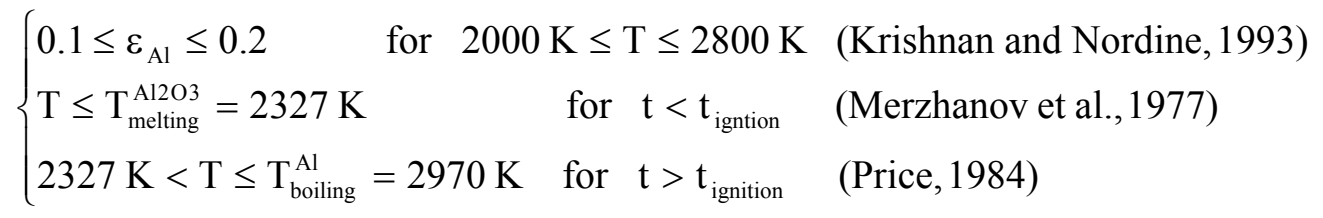

In a previous study in other atmospheres (Sarou-Kanian et al., 2004) we have found:

$$
\begin{cases}\varepsilon_{\exp } / \varepsilon_{\mathrm{Al} 2 \mathrm{O} 3} \geq 0.34 \pm 0.05 & \text { for } \mathrm{t}<\mathrm{t}_{\text {igntion }} \\ 0.24 \pm 0.02 \leq \varepsilon_{\exp } / \varepsilon_{\mathrm{Al} 2 \mathrm{O} 3} \leq 0.31 \pm 0.02 & \text { for } \mathrm{t}>\mathrm{t}_{\text {ignition }}\end{cases}
$$

During the combustion, the smallest values of the emissivity ratio were obtained just after ignition and the highest values at the steady process. So we have chosen $\varepsilon_{\exp } / \varepsilon_{\mathrm{Al2O} 3}=0.30 \pm 0.03$. Table I summarizes the different values of droplet temperature in the steady combustion phase. For wet $\mathrm{CO}_{2}$ and $\mathrm{H}_{2} \mathrm{O} / \mathrm{CO}_{2}$ mixtures, the droplet temperature is 
steady around $2600 \mathrm{~K}$. However, for the ternary mixtures $\mathrm{H}_{2} \mathrm{O} / \mathrm{CO}_{2} / \mathrm{N}_{2}, \mathrm{~T}_{\text {droplet }}$ is lower around $2450 \mathrm{~K}$, and for wet $50 \% \mathrm{CO}_{2} / 50 \% \mathrm{~N}_{2}, \mathrm{~T}_{\text {droplet }}$ is $2500 \mathrm{~K}$ but with the laser kept on heating.

\section{Droplet and oxide cap sizes evolution}

From the images recorded by the high-speed camera (Figure 1), it is quite easy to measure the temporal evolution of the burning droplet and the oxide cap dimensions. About twenty frames are carefully selected for their good quality (clear droplet contours) and their representativeness (periodicity in time). The Al droplet being quasi spherical (deformations < $1 \%$ ), the measure of the projected area of the droplet surface provides the squared diameter with a suitable uncertainty $(<5 \%)$. For the oxide cap, only its circular basis is evaluated. As the cap moves on the droplet surface, its projection is an ellipse for the observer. However the ellipse major axis always corresponds to the radius of the projected circle.

\section{Burning rates}

Figure 4 illustrates the evolution of the reduced squared diameter $\left(\mathrm{d}^{2} / \mathrm{d}_{0}{ }^{2}\right)$ as a function of the reduced time $\left(\mathrm{t} / \mathrm{d}_{0}{ }^{2}\right)$ for the $\mathrm{CO}_{2}$ containing atmospheres. We can see clearly that the regression of $\mathrm{Al}$ burning droplet size depends on the oxidizing atmosphere nature $\left(\mathrm{H}_{2} \mathrm{O}, \mathrm{CO}_{2}\right)$ and concentration. From these experimental data, the burning rate $\beta$ is easily deduced as the slope of the linear regression fitting and expressed in $\mathrm{mm}^{2} / \mathrm{s}$. As summarized in Table I, the burning rate decreases with the addition of $\mathrm{CO}_{2}$ in $\mathrm{H}_{2} \mathrm{O} / \mathrm{CO}_{2}$ mixtures, and with the substitution of $\mathrm{CO}_{2}$ by nitrogen in the ternary mixtures. The lowest $\beta$ is obtained in wet $50 \% \mathrm{CO}_{2} / 50 \% \mathrm{~N}_{2}$. 


\section{"d" law"}

In Figure 4 it can be observed that the droplet size evolution expressed in squared diameter deviates from linearity for the highest $\mathrm{CO}_{2}$ concentrations in comparison to the lowest ones. This means that the well known " $\mathrm{d}^{2}$ law" seems inappropriate, and it would be better to use a “d ${ }^{n}$ law” suggested by several previous works (Friedman and Maček, 1962; Davis, 1963; Wilson and Williams, 1971; Prentice, 1974; Zenin et al.,1999, 2000; Rossi et al., 2001; Melcher et al., 2000, 2002). Thus, the exponent $n$ was estimated by a non-linear least squared fitting with the Levenberg-Marquardt algorithm (Origin 5.0 software). The mean values of $n$ summarized in Table I show that it decreases with the addition of $\mathrm{CO}_{2}$ from 1.7 to 0.6.

\section{Estimated stagnant burning rates}

Because the Al droplet burns in the flow of oxidizing levitation gases, the experimental burning rates which were deduced from the droplet size regressions are influenced by forced convective effects. In order to estimate the burning rates in a stagnant atmosphere, an evaluation of the heat and mass transfer rates under forced convection should be preliminary done.

The Nusselt and Sherwood numbers ( $\mathrm{Nu}$ and $\mathrm{Sh})$ characterizing heat and mass transfer are generally expressed in terms of correlations depending on the Reynolds (Re), Prandtl (Pr), and Schmidt (Sc) numbers. The most commonly used correlation is given by Ranz and Marshall (1952):

$$
\left\{\begin{array}{l}
\mathrm{Nu}=2+0.555 \cdot \mathrm{Re}^{\frac{1}{2}} \cdot \operatorname{Pr}^{\frac{1}{3}} \\
\mathrm{Sh}=2+0.555 \cdot \mathrm{Re}^{\frac{1}{2}} \cdot \mathrm{Sc}^{\frac{1}{3}}
\end{array}\right.
$$

For the calculation of the Reynolds number, we have assumed that the aerodynamic levitation of our $\mathrm{Al}$ droplet is equivalent to the aerodynamic equilibrium of a droplet free falling in a gas 
flow. Re was calculated only at the initial diameter $\left(\mathrm{d}_{0}=3.15 \mathrm{~mm}\right)$. The Prandtl and Schmidt numbers were estimated by considering the thermophysical properties of gases $\left(\mathrm{Al}_{\mathrm{g}}, \mathrm{H}_{2}, \mathrm{CO}\right.$, $\mathrm{N}_{2}$ ) at the reference temperature $\mathrm{T}_{\text {ref }}=\left(\mathrm{T}_{\text {droplet }}+\mathrm{T}_{\text {flame }}\right) / 2$ (Wiskel et al., 2002). The uncertainties on Re and Pr are about 50\%. The stagnant burning rates were obtained from the expression:

$\beta_{\text {Stag }}=4 \cdot \frac{\beta_{\text {Exp }}}{(\mathrm{Nu}+\mathrm{Sh})}$

The uncertainties on $\mathrm{Nu}, \mathrm{Sh}$, and $\beta_{\text {stag }}$ are about $30 \%$. Table I summarizes the different values

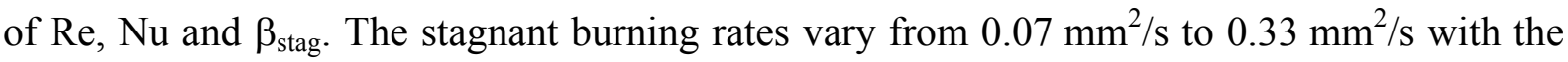
same hierarchy as in the convective atmospheres.

\section{Oxide cap regression rates}

It is the first time that the oxide cap regression is clearly described; it is generally considered that the contrary (accumulation) rather takes place (Friedman and Maček, 1962; Prentice 1974; Dreizin, 1996; Zenin et al., 1999, 2000, 2001). To our knowledge, there is no theory describing the processes of oxide cap regression. Thus, in order to have an idea of the evolution of oxide cap size, the exponent $n$ of a " $\mathrm{d}^{n}$ law" similar to the Al burning droplet was estimated. Several values were tested: $n=1,1.5,2$, and 3 . In most of the atmospheres, the value $n=2$ was the best fitting parameter (Figure 5). Therefore, we have deduced an oxide cap rate noted $K$ and expressed in $\mathrm{mm}^{2} / \mathrm{s}$. Table I summarizes the mean values of $K$ for most studied atmospheres. For the $\mathrm{H}_{2} \mathrm{O} / \mathrm{CO}_{2}$ mixtures, the oxide cap rate is rather constant around $K=0.35 \pm 0.04 \mathrm{~mm}^{2} / \mathrm{s}$. However the addition of nitrogen decreases the oxide cap regression process $\left(K=0.19 \pm 0.02 \mathrm{~mm}^{2} / \mathrm{s}\right.$ for $\mathrm{H}_{2} \mathrm{O} / \mathrm{CO}_{2} / \mathrm{N}_{2}$ and $K=0.14 \pm 0.02 \mathrm{~mm}^{2} / \mathrm{s}$ for wet $\left.50 \% \mathrm{CO}_{2} / 50 \% \mathrm{~N}_{2}\right)$. 


\section{Unburnt residues}

Two kinds of unburnt residues are collected: the slowly cooled residues (in the levitation gases) and the fast quenched ones (impact on the sides of the levitator).

The first category concerns particularly some $\mathrm{Al}$ droplet burning in wet $\mathrm{CO}_{2}$. Under these conditions of cooling, crystallized phases are formed and analyzed by X-Ray Diffraction. Three phases are identified: metallic aluminum, aluminum carbide $\left(\mathrm{Al}_{4} \mathrm{C}_{3}\right)$ and aluminum oxycarbide $\left(\mathrm{Al}_{4} \mathrm{O}_{4} \mathrm{C}\right)$.

The second category contains most of the residues whatever the gaseous atmosphere. The first interesting fact is about the global surface morphology of unburnt residues in high $\mathrm{CO}_{2}$ concentrations $\left(\mathrm{x}_{\mathrm{CO} 2} \geq 0.5\right)$. As illustrated in Figure 6 , the morphology of the residues is singular: on a mother sphere, one or several smaller satellite spheres are attached. Furthermore, the Back Scattering Electron mode (BSE - chemical contrast) has shown (Figure 6-a) that the surfaces of the mother sphere and its satellites have a different chemical composition. The surface of mother spheres is also very remarkable because it looks like a "wool-ball" with this "fiber entanglement" (Figure 6-b-c). On Figure 6-c, we can also observe that a part of these "fibers" is separated from the surface as a thin plate. A detail of the structure which is just below (Figure 6-d) seems to indicate the presence of a skeleton inside the residue. This observation was confirmed by the cross-sectioned residues. As illustrated in Figure 7, the mother residues are constituted of an aluminum matrix (white-light grey zones) with several cavities (dark zones) and thin needles (dark grey zones). In reality, these needles correspond to an entanglement of plates forming a skeleton the density of which increases with the $\mathrm{CO}_{2}$ concentration. An analysis of this skeletal phase by EDS allowed the detection of an aluminum oxycarbide with a non-stoichiometric composition such as $\mathrm{AlO}_{0.13} \mathrm{C}_{0.46}$ which was always the same for all residues. Furthermore, an analysis of the Al matrix has also shown $(3 \pm 1) \%$ mol $\mathrm{C}$ and $(5 \pm 1) \%$ mol O. In addition to the EDS analysis, a global 
quantification of carbon by nuclear activation in some unburnt residues in different $\mathrm{CO}_{2}$ containing atmospheres was carried out. We have observed (Table II) that the molar fraction of carbon in the residues rapidly increases with the $\mathrm{CO}_{2}$ concentration up to a steady value around $20-23 \%$ mol C.

\section{DISCUSSION}

\section{Gas-Phase processes}

\section{Burning rates}

The main criterion characterizing the gas-phase combustion of Al droplets is the burning rate ( $\beta)$. The evaluation of $\beta$ in several $\mathrm{CO}_{2}$ containing atmospheres has shown that the increase of the proportion of carbon dioxide in the mixture decreases it. In terms of efficiency to burn rapidly an aluminum droplet, this suggests that $\mathrm{CO}_{2}$ is a worse oxidizer than $\mathrm{H}_{2} \mathrm{O}$. This observation was already made by Olsen and Beckstead (1995). In order to take into account the influence of the nature and of the concentration of $\mathrm{CO}_{2}$ on the burning rate, an "oxidizer efficiency" is estimated from the following correlation similar to the model proposed by Brooks and Beckstead (1995):

$\beta=\beta_{0} \cdot \sum_{\mathrm{i}} \mathrm{x}_{\mathrm{i}} \cdot \mathrm{e}_{\mathrm{i}}$

$\beta_{0}$ is the reference burning rate, $x_{i}$ the molar fraction and $e_{i}$ the "oxidizer efficiency" coefficient of $i$-th species. We have considered $\mathrm{H}_{2} \mathrm{O}$ as the reference species, i.e. $e_{H_{2} O}=1$ and $\beta_{0}=\beta\left(100 \% \mathrm{H}_{2} \mathrm{O}\right)$. Note that a weight factor was also attributed to nitrogen $\left(e_{N 2}\right)$ with the same definition as the "oxidizer efficiency" coefficient. We have found $e_{\mathrm{CO} 2}=(0.38 \pm 0.05)$. However, for Olsen and Beckstead (1995), Legrand (2000), or Servaites et al. (2001), the reference species was $\mathrm{O}_{2}\left(e_{O 2}=1\right)$. In previous work (Sarou-Kanian et al., 2004), we have also evaluated the influence of $\mathrm{O}_{2}$ in $\mathrm{H}_{2} \mathrm{O} / \mathrm{O}_{2}$ and we have found $e_{O 2}=(2.09 \pm 0.22)$. Thus, by 
normalizing from $\mathrm{O}_{2}$ instead of $\mathrm{H}_{2} \mathrm{O}$, we have obtained $e_{H 2 O}=(0.48 \pm 0.05)$, and $e_{\mathrm{CO} 2}=(0.18 \pm 0.02)$ which are in good agreement with Olsen and Beckstead (1995) $\left(e_{\mathrm{H} 2 \mathrm{O}}=0.53 ; e_{\mathrm{CO} 2}=0.14\right)$ and Legrand (2000) $\left(e_{\mathrm{CO} 2}=0.14\right)$. These estimations of "oxidizer efficiencies" allow establishing a hierarchy between the three major oxidizers such as $e_{\mathrm{O} 2} \approx 2 \cdot e_{\mathrm{H} 2 \mathrm{O}} \approx 6 \cdot e_{\mathrm{CO} 2}$. However this parameter does not explain what is their real influence on the combustion processes. Indeed, we can observe that the droplet temperature is quite similar in the $\mathrm{H}_{2} \mathrm{O} / \mathrm{CO}_{2}$ atmospheres $\left(\mathrm{T}_{\text {droplet }} \approx 2600 \mathrm{~K}\right)$ and the ternary $\mathrm{H}_{2} \mathrm{O} / \mathrm{CO}_{2} \mathrm{~N}_{2}\left(\mathrm{~T}_{\text {droplet }} \approx 2450 \mathrm{~K}\right)$ while the burning rates are completely different. For example, the burning rate is higher for $50 \% \mathrm{H}_{2} \mathrm{O} / 25 \% \mathrm{CO}_{2} / 25 \% \mathrm{~N}_{2}\left(\beta=1.41 \mathrm{~mm}^{2} / \mathrm{s}\right)$ with $\mathrm{T}_{\text {droplet }}=2450 \mathrm{~K}$ than in $20 \% \mathrm{H}_{2} \mathrm{O} / 80 \% \mathrm{CO}_{2}$, $12.5 \% \mathrm{H}_{2} \mathrm{O} / 87.5 \% \mathrm{CO}_{2}$, and wet $\mathrm{CO}_{2}$ (respectively $\beta=1.38-1.32-1.28 \mathrm{~mm}^{2} / \mathrm{s}$ ) with $\mathrm{T}_{\text {droplet }} \approx 2600 \mathrm{~K}$. This fact confirms that the droplet vaporization is controlled by the mass transfer in the gas-phase. In the intermediate zone between the droplet and the flame, the gaseous atmosphere is very reducing and is essentially composed of aluminum vapor diffusing from the droplet surface and of gaseous species produced by the combustion diffusing from the flame. Among these gaseous products, there are some transitional molecules (AlO) and mainly stable ones such as $\mathrm{H}_{2}$ or $\mathrm{CO}$. Furthermore, some gases do not really react with $\mathrm{Al}$ such as $\mathrm{N}_{2}$ and can cross the flame and diffuse also to the droplet. Thus, the $\mathrm{Al}$ vapor has to diffuse through these species to attain the flame front, and it is this mass transfer by molecular diffusion which controls the vaporization process. If $\mathrm{CO}$ and $\mathrm{N}_{2}$ have quite the same thermophysical properties (density, heat capacity, thermal conductivity, viscosity, self-diffusion), $\mathrm{H}_{2}$ has completely different ones because it is a light gas (highest $\mathrm{C}_{\mathrm{p}}, \lambda$ and $\mathcal{D}$; lowest $\rho$ and $\mu$ ) (Widener and Beckstead, 1998). The main consequence is that $\mathrm{H}_{2}$ allows a better inter-molecular diffusion with $\mathrm{Al}$ than $\mathrm{CO}$ or $\mathrm{N}_{2}$ which involves a better vaporization, i.e. a better burning rate. 


\section{"d ${ }^{n}$ law"}

The evaluation of the exponent $n$ of the " $\mathrm{d}^{n}$ law" for some $\mathrm{CO}_{2}$ containing atmospheres has shown that $n$ decreases with the increase of $\mathrm{CO}_{2}$ from 1.7 to 0.6 . Note that $n \approx 2$ in $100 \% \mathrm{H}_{2} \mathrm{O}$ (see Table I). From an analytical point of view, $n=2$ means that the combustion is controlled by thermal or molecular diffusion, and $n=1.5$ should correspond to the influence of the convective effect (Kuo, 1986). We can observe that we did not often verify $n=1.5$ while the forced convection is undoubtedly present in our experimental conditions. Actually, it is advisable to be very careful with this kind of parameter, because, similarly to the "oxidizer efficiency" coefficient $e_{i}$, the estimation of $n$ mainly aims to allow a good compilation of the experimental data in order to compute an efficient numerical model. Thus, if one would conclude that the combustion is diffusion-controlled only in pure $\mathrm{H}_{2} \mathrm{O}$ from " $\mathrm{d}^{2}$ law" argument, but not in the other atmospheres would be a great mistake. For example, the burning rate for the most probable value of $n$ in $20 \% \mathrm{H}_{2} \mathrm{O} / 80 \% \mathrm{CO}_{2}$ was $\beta_{n}=0.16 \mathrm{~mm}^{0.72} / \mathrm{s}$. Now if we calculate the burning time for a typical Al particle in solid propellant with a diameter of $50 \mu \mathrm{m}$, we obtain $\mathrm{t}_{\mathrm{c}}=\mathrm{d}_{0}{ }^{n} / \beta_{n}=723 \mathrm{~ms}$ which is completely unrealistic (generally $\left.\mathrm{t}_{\mathrm{c}}<10 \mathrm{~ms}\right)$. This fact is confirmed by Zenin et al. $(1999,2000,2001)$ who observed the change of the exponent $n$ with the initial Al particle diameter. However we can remark a similarity with the works of Prentice (1974) and Zenin et al. $(1999,2000,2001)$ for the variation of $n$ with the gaseous atmosphere which suggests that the heat and mass transfer properties of the gas-phase are probably responsible of these curious behavior.

\section{Stagnant burning rates}

The stagnant burning rates calculated by correcting for the convective effect of the experimental rates vary from 0.07 to $0.33 \mathrm{~mm}^{2} / \mathrm{s}$ versus the $\mathrm{CO}_{2}$ concentration. The comparison with previous studies on micrometric and submillimetric aluminum particles 
burning in $\mathrm{CO}_{2}$ containing atmospheres shows (Figure 8 ) that the highest $\beta_{\text {stag }}(\approx 0.2-$ $\left.0.3 \mathrm{~mm}^{2} / \mathrm{s}\right)$ are more consistent rather than the smallest ones $\left(\approx 0.1 \mathrm{~mm}^{2} / \mathrm{s}\right)$. The main reason is probably the uncertainties concerning the evaluation of the forced convection. Indeed, several assumptions on the aerodynamic configuration and on the thermophysical properties had to be done to calculate the characteristic numbers (Re, $\mathrm{Pr}, \mathrm{Sc}, \mathrm{Nu}, \mathrm{Sh})$. If we consider that the stagnant burning rates are underestimated in comparison with the other works, it means that the convective effect is overestimated. In the classical correlations taking into account the forced convection (see equation 5), the major parameter is the Reynolds number $\left(\operatorname{Re}^{1 / 2}\right)$; the influence of the other numbers (Prandtl or Schmidt) is quite minor because they are generally close to unity and the 1/3-power makes them tend towards 1 anyway. It is therefore possible that the Reynolds number is overestimated or that its estimation on the initial droplet diameter is misleading.

\section{Heterogeneous processes}

\section{Oxide cap}

The oxide cap regression occurred in all gaseous atmospheres and was already observed for $\mathrm{H}_{2} \mathrm{O} / \mathrm{O}_{2}, \mathrm{H}_{2} \mathrm{O} / \mathrm{N}_{2}$ and $\mathrm{H}_{2} \mathrm{O} / \mathrm{Ar}$ mixtures by Sarou-Kanian et al. (2004). Such phenomenon seems to contradict previous studies observing the accumulation of oxide on the surface of quenched Al particles (Dreizin, 1996; Zenin et al., 1999, 2000, 2001). However, it has to be noticed the oxide accumulation was not always found (Prentice, 1970; Wilson and Williams, 1971; Dreizin, 1999; Rossi et al., 2001). As it was suggested by Sarou-Kanian et al. (2004), the oxide cap regression probably corresponds to the chemical decomposition of liquid alumina (cap) by reducers producing gaseous aluminum oxides such as $\mathrm{AlO}, \mathrm{Al}_{2} \mathrm{O}(\mathrm{Olsen}$ and Beckstead, 1995 ; Babuk and Vassiliev, 2002). Of course, the main reducer is liquid 
aluminum (droplet), but reducing gases such as $\mathrm{Al}_{(\mathrm{g})}, \mathrm{H}_{2}$, or $\mathrm{CO}$ may also react. Thus, the reaction $\mathrm{Al}_{(1)}+\mathrm{Al}_{2} \mathrm{O}_{3(1)}$ directly depending on the temperature $\left(\mathrm{P}_{\mathrm{Al} 2 \mathrm{O}}(2600 \mathrm{~K}) \approx 13 . \mathrm{P}_{\mathrm{Al} 2 \mathrm{O}}(2450 \mathrm{~K})\right)$, there is a strong correlation between the oxide cap regression rate and the droplet temperature. Indeed, for $\mathrm{H}_{2} \mathrm{O} / \mathrm{CO}_{2}$ and $\mathrm{H}_{2} \mathrm{O} / \mathrm{CO}_{2} / \mathrm{N}_{2}$ mixtures, $K$ is $0.35 \pm 0.04 \mathrm{~mm}^{2} / \mathrm{s}$ at $2600 \mathrm{~K}$ and $0.19 \pm 0.02 \mathrm{~mm}^{2} / \mathrm{s}$ at $2450 \mathrm{~K}$.

Furthermore, it is confirmed that nitrogen also plays a role in the slowing down of the chemical decomposition process which is particularly manifest for wet $50 \% \mathrm{CO}_{2} / 50 \% \mathrm{~N}_{2}$. The explanation is very speculative, but it is proposed that nitrogen may inhibit the reaction between the Al droplet and the oxide cap (Sarou-Kanian et al., 2004).

\section{Surface and internal phase changes}

The observations and analyses of the unburnt residues have shown that several phenomena occur during cooling both at the surface (a wool-ball like mother sphere with smaller attached satellites) and in the bulk (formation of an aluminum oxycarbide skeleton and presence of cavities). Actually, the surface phenomena are directly a consequence of the internal phase changes.

First of all, the voids inside the residues result from the gasification of dissolved elements during the solidification of the liquid Al matrix ( $\mathrm{T}=933 \mathrm{~K}$ ). The cavities being only observed in residues burning in water-based atmospheres (Sarou-Kanian et al., 2004), it demonstrates that it is due to the hydrogen dissolution (Talbot, 1975). As the aluminum oxycarbide skeleton is already formed $\left(\mathrm{T} \approx 2400 \mathrm{~K}\right.$, see below), most of $\mathrm{H}_{2}$ is trapped in the residue in polyhedral cavities. But though the amount of dissolved hydrogen is very low $\left(\mathrm{x}_{\mathrm{H}}<10^{-4}\right)$, its gasification in these exiguous cavities involves high pressures. Thus, in some cases, the gas pressure is 
sufficient to push the liquid aluminum outside the residue which forms these satellites at the surface (Figure 9).

The identification of stoichiometric and non-stoichiometric aluminum carbide and oxycarbide phases inside the unburnt residues in $\mathrm{CO}_{2}$ containing atmospheres demonstrates the dissolution of carbon and oxygen during the combustion process. Contrary to nitrogen or hydrogen (Sarou-Kanian et al., 2004), the amount of dissolved carbon and oxygen are really significant $\left(\% \mathrm{C}_{\max } \approx 20-23 \% \mathrm{~mol} ; \% \mathrm{O}_{\max } \approx 5-7 \% \mathrm{~mol}\right)$. Such concentrations confirm those reported by Rossi et al. (2001) for burning $100-250 \mu \mathrm{m}$ particles in pure $\mathrm{CO}_{2}(\% \mathrm{C} \approx 18 \% \mathrm{~mol}$; $\% \mathrm{O} \approx 4 \% \mathrm{~mol})$. The dissolution process is not clearly identified, but it may result from surface reactions between liquid $\mathrm{Al}$ and gaseous carbon and oxygen containing species; it is probably carbon monoxide $(\mathrm{CO})$ because it contains both carbon and oxygen, and it is the main gas produced in the flame by the reaction with $\mathrm{CO}_{2}$ which can then diffuse to the droplet. Such process may be controlled by heterogeneous kinetics (absorption on the surface) and diffusion mechanisms (transport in the bulk). One experimental evidence is the lowest carbon amount obtained for the lowest $\mathrm{CO}_{2}$ concentration $\left(20 \% \mathrm{CO}_{2}, \mathrm{x}_{\mathrm{c}} \approx 3.5-4.5 \%\right)$ which suggests the $\mathrm{CO}_{2}$ partial pressure dependence characterizing heterogeneous kinetics effects.

The different compositions obtained by XRD $\left(\mathrm{Al}_{4} \mathrm{C}_{3}, \mathrm{Al}_{4} \mathrm{O}_{4} \mathrm{C}\right)$ and by $\mathrm{EDS}\left(\mathrm{AlO}_{0.13} \mathrm{C}_{0.46}\right)$ question the real nature of the skeleton. Nevertheless, it can be argued that the samples analyzed by RDX or by EDS have different cooling rates: the formers are cooled slowly in the levitation gases $(\mathrm{t}>1 \mathrm{~s})$ while the latters are rapidly quenched by impacting the sides of the levitator $(50<\mathrm{t}<100 \mathrm{~ms})$. Thus, the non-stoichiometric compound $\mathrm{AlO}_{0.13} \mathrm{C}_{0.46}$ could be a metastable phase at high temperature frozen at impact of the residue, contrary to the stoichiometric and stable phases $\mathrm{Al}_{4} \mathrm{C}_{3}$ and $\mathrm{Al}_{4} \mathrm{O}_{4} \mathrm{C}$ which could be formed during the slower 
cooling. Rossi et al. (2001) have found two non-stiochiometric aluminum oxycarbides: $\mathrm{AlO}_{0.025} \mathrm{C}_{0.059}$ and $\mathrm{AlO}_{0.13} \mathrm{C}_{0.63}$. The latter is close to our finding but it is richer in carbon. Furthermore, these non-stoichiometric compounds do not correspond to a $\mathrm{Al}_{2} \mathrm{O}_{3}-\mathrm{Al}_{4} \mathrm{C}_{3}$ mixture; there is always an excess of aluminum $\left(\mathrm{AlO}_{0.13} \mathrm{C}_{0.46}=0.042 \mathrm{Al}_{2} \mathrm{O}_{3}+0.153 \mathrm{Al}_{4} \mathrm{C}_{3}+\right.$ $0.302 \mathrm{Al}$ ) confirming that they are metastable phases.

If we consider the binary phase diagram of aluminum and carbon (Figure 10), it is observed that in the droplet temperature range $[2450-2650 \mathrm{~K}]$ corresponding to the combustion in $\mathrm{H}_{2} \mathrm{O} / \mathrm{CO}_{2} / \mathrm{N}_{2}$ and $\mathrm{H}_{2} \mathrm{O} / \mathrm{CO}_{2}$ mixtures, liquid $\mathrm{Al}$ can dissolve up to $20-25 \%$ mol of carbon which represents exactly the quantity of carbon found in the unburnt residues for $\mathrm{x}_{\mathrm{CO}_{2}}>0.4$ (see Table II). This consideration allows understanding the surface phenomena which were observed for combustion in high $\mathrm{CO}_{2}$ concentrations: formation of a solid phase and sudden light emission (Figure 2). Indeed, this means that the $\mathrm{Al}$ droplets burning in these atmospheres have reached the carbon saturation limit and that no carbon can be dissolved anymore (Figure 10, step 1). However, as the droplet size continues to decrease because of Al vaporization, it will inevitably contain an excess of carbon which will be then ejected at the surface forming a solid coating (step 2) as observed in Figure 2, Frames 2-3. As a result, this coating prevents the Al vaporization and stops the gas-phase burning; the droplet temperature begins to decrease (step 3, Figure 2, Frames 4-5) down to the crystallization temperature of the aluminum oxycarbide. Obviously, it is aluminum carbide $\left(\mathrm{Al}_{4} \mathrm{C}_{3}\right)$ on the $\mathrm{Al}-\mathrm{C}$ phase diagram and not $\mathrm{AlO}_{0.13} \mathrm{C}_{0.46}$. Nevertheless, we can assume that the $\mathrm{Al}-\mathrm{O}-\mathrm{C}$ system with $5-7 \% \mathrm{~mol}$ of oxygen is not completely different to the Al-C system in terms of carbon saturation limit and aluminum carbide or metastable oxycarbide dissociation/crystallization temperature $(\sim 2400 \mathrm{~K})$. So when the crystallization of $\mathrm{AlO}_{0.13} \mathrm{C}_{0.46}$ occurs (step 4$)$, there is an exothermic reaction leading to the sudden light emission of the droplet (Figure 2, Frame 6). 
The last point concerns the solid phase formed at the droplet burning surface in wet $50 \% \mathrm{CO}_{2} / 50 \% \mathrm{~N}_{2}$. As described in the "Visual observations" part, this solid coating is different from the one observed for the other $\mathrm{CO}_{2}$ containing atmospheres (longer time to complete cover) and corresponds to aluminum nitride (AlN). This case is singular because the unburnt residues contain also large amounts of carbon $(21.5 \pm 1.5 \%$ mol), i.e. near the saturation limit. Thus, the fact that it is the AlN formation rather than the carbon ejection which leads to the droplet cover is quite enigmatic. This consideration also reveals another question: why the AlN coating was not observed for the ternary $\mathrm{H}_{2} \mathrm{O} / \mathrm{CO}_{2} / \mathrm{N}_{2}$ mixtures? Indeed, this phenomenon was always observed for $\mathrm{Al}$ droplet burning in $\mathrm{H}_{2} \mathrm{O} / \mathrm{N}_{2}$ mixtures with similar nitrogen concentrations (Sarou-Kanian et al., 2004). For these experiments, it was observed that the time of AlN formation decreased with the addition of nitrogen, i.e. $\mathrm{t}=2.2 \pm 0.2 \mathrm{~s}$ for $20 \% \mathrm{~N}_{2}$, and $\mathrm{t}=1.25 \pm 0.3 \mathrm{~s}$ for $50 \% \mathrm{~N}_{2}$; in the present work, we obtained $\mathrm{t}=7.25 \pm 1.25 \mathrm{~s}$ for wet $50 \% \mathrm{CO}_{2} / 50 \% \mathrm{~N}_{2}$. This means that, for the same $\mathrm{N}_{2}$ partial pressure (50\%), the time of AlN formation is about 6 times greater when $\mathrm{H}_{2} \mathrm{O}$ is replaced by $\mathrm{CO}_{2}$. Attempt to explain this observation is rather speculative but it can be stated that the diffusion of $\mathrm{N}_{2}$ from the flame to the droplet may be slower when $\mathrm{H}_{2}$ is replaced by $\mathrm{CO}$ (see part "Discussion-Gas-phase processes"), or/and the carbon dissolution may promote as well the nitrogen dissolution (Qiu and Metselaar, 1997). Nevertheless, what we can conclude is that $\mathrm{CO}_{2}$ seems to slow down or delay the nitride coating formation. Therefore, $\mathrm{AlN}$ is not formed on the $\mathrm{Al}$ droplet surface burning in $\mathrm{H}_{2} \mathrm{O} / \mathrm{CO}_{2} / \mathrm{N}_{2}$ mixtures probably because the time of $\mathrm{AlN}$ formation is longer than the burning time (the burning rates are higher for $\mathrm{H}_{2} \mathrm{O} / \mathrm{CO}_{2} / \mathrm{N}_{2}$ than for wet $50 \% \mathrm{CO}_{2} / 50 \% \mathrm{~N}_{2}$ ). 


\section{Synthesis and prospects}

From the interpretation of these different results describing both gas-phase and heterogeneous processes, some important information about the combustion of $\mathrm{Al}$ droplet in $\mathrm{CO}_{2}$ containing atmospheres can be derived. First, it is confirmed that $\mathrm{CO}_{2}$ is the worst oxidizer in comparison with $\mathrm{O}_{2}$ and $\mathrm{H}_{2} \mathrm{O}$ in terms of burning rate. Second, as it was shown by Rossi et al. (2001), carbon can be dissolved in large amounts (up to 20-25\% mol C) in liquid aluminum during combustion. Third, we have demonstrated that when the carbon saturation limit is reached, the excess of carbon is ejected at the surface leading to the end of the gas-phase burning. In fact, this last point reveals the competition between homogeneous (vaporization) and heterogeneous (dissolution) processes, and here is probably the crucial role of carbon dioxide. Indeed, the quantity of carbon dissolved in Al droplets of different sizes (millimetric - present work; submillimetric - Rossi et al., 2001), will inevitably reach its saturation limit because of the continuing Al vaporization, involving the carbon ejection and the gas-phase combustion ending. Furthermore, the carbon dissolution has also a direct effect on the gas-phase burning by limiting the $\mathrm{Al}$ vaporization; as illustrated in Figure 11, the vapor pressure of aluminum may decrease up to $30 \%$ when the molar fraction of dissolved carbon is about $25 \%$.

It should be noted that our work consisted in the study of Al droplets in cooled atmospheres and not in hot gases as in solid propellant conditions. Therefore, if the gas-phase Al combustion is stopped due to carbon coating, direct surface reactions are still possible in hot environments, which means the establishment of a new (heterogeneous) combustion regime. This consideration is an interesting assumption for the understanding of the aluminum droplet combustion in $\mathrm{CO}_{2}$ atmospheres. 


\section{CONCLUSION}

The combustion of millimetric aluminum droplets aerodynamically levitating in $\mathrm{CO}_{2}$ containing atmospheres has been studied. This work aimed to describe and understand more precisely the influence of carbon dioxide on the combustion processes both in gas-phase, at the droplet surface, and inside the droplet. Detailed visual observations, burning rate and droplet temperature measurements, an analysis of unburnt residues, allowed global understanding of most of the processes occurring during $\mathrm{Al}$ droplet combustion in $\mathrm{CO}_{2}$.

The ignition and first steps of burning are similar to the experiments in other oxidizing atmospheres: oxide coating breakdown which liquefies as an initial cap, formation of a diffusion flame, regression of droplet and cap sizes. However, for high $\mathrm{CO}_{2}$ concentrations, a solid phase suddenly appears and rapidly covers the droplet preventing the $\mathrm{Al}$ vaporization and stopping the combustion. This solid coating results from the dissolution of significant amounts of carbon in liquid $\mathrm{Al}$ (up to $20-23 \%$ mol C) the excess of which is ejected at the droplet surface when the carbon saturation limit is reached. The evaluation of the burning rates in several $\mathrm{CO}_{2}$ containing atmospheres has shown that $\mathrm{CO}_{2}$ is a worst oxidizer than $\mathrm{O}_{2}$ or $\mathrm{H}_{2} \mathrm{O}$. The exponent $n$ deduced from an hypothetic " $\mathrm{d} n$ law" varies for different atmospheres. The determination of the oxide cap regression rates confirms that the oxide cap disappearance corresponds to the chemical decomposition of alumina by aluminum.

In conclusion, carbon dioxide is probably the oxidizer with the most complex mechanisms because it reacts in the flame by producing $\mathrm{CO}$ which diffuses back to the droplet and reacts with liquid $\mathrm{Al}$ to give dissolved carbon (and oxygen). This increase of the carbon quantity up to its saturation limit progressively decreases the $\mathrm{Al}$ vaporization process, and finally stops the gas-phase burning with the carbon ejection. Nevertheless, the end of homogenous combustion may not mean the end of combustion; heterogeneous reactions may still exist in 
solid propellant conditions (hot gases). The existence of this second combustion regime has to be investigated in future work.

\section{REFERENCES}

Babuk, V.A., and Vasilyev, V.A. (2002), Model of aluminum agglomerate evolution in combustion products of solid rocket propellant, J. Prop. Power, 18:4, 814.

Brooks, K.P., and Beckstead, M.K. (1995), Dynamics of aluminum combustion, J. Prop. Power, 11:4, 769.

Bucher, R.A., Yetter, R.A., Dryer, F.L., Vicenzi, E.P., Parr, T.P., and Hanson-Parr, D.M. (1999), Condensed-phase species distributions about Al particles reacting in reacting in various oxidizers, Combust. Flame, 117, 351.

Davis, A. (1963), Solid propellants: The combustion of particles of metal ingredients, Combust. Flame, 7, 359.

Dreizin, E.L. (1996), Experimental study of stages in aluminum particle combustion in air, Combust. Flame, 105, 541.

Dreizin, E.L. (1999), On the mechanism of asymmetric of aluminum particle combustion, Combust. Flame, 117, 841.

Ernst, L.F., Dryer, F.L., and Yetter, R.A. (2000), Oxidative aluminum particle combustion in high pressure environments, $37^{\text {th }}$ Combustion $/ 25^{\text {th }}$ Airbreathing Propulsion/19 ${ }^{\text {th }}$ Propulsion Systems Hazards $/ 1^{\text {st }}$ Modeling and Simulation Subcommittees Joint Meeting, Monterey.

Freidman, R., and Maček, A. (1962), Ignition and combustion of aluminium particles in hot ambient gases, Combust. Flame, 6, 9.

Glorieux, B., Millot, F., Rifflet, J.C., and Coutures, J.P. (1999), Density of superheated and undercooled liquid alumina by a contactless method, Int. J. of Thermophysics, 20:4, 1085. 
Glorieux, B., Millot, F., and Rifflet, J.C. (2002), Surface tension of liquid alumina from contactless techniques, Int. J. of Thermophysics, 23, 249.

Gokcen, N.A., and Oden, L.L. (1998), Phase equilibria in aluminium-carbon system at high temperatures, Ber.Bunsenges. Phys. Chem., 102:9, 1178.

Krishnan, S., and Nordine, P.C. (1993), Optical properties of liquid aluminum in the energy range 1.2-3.5 eV, Phys. Rev. B, 47:18, 11780 .

Kuo, K.K. (1986), Principles of combustion, Wiley, New-York, pp. 371-397.

Legrand, B. (2000), Etude de la combustion de particules d'aluminium et de magnésium: influence de la composition du mélange gazeux et de la pression, Thesis, Orléans University, France.

Legrand, B., Marion, M., Chauveau, C., Gökalp, I., and Shafirovich, E. (2001), Ignition and combustion of levitated magnesium and aluminum particles in carbon dioxide, Combust. Science and Technology, 165, 151.

Marion, M. (1996), Etudes sur la combustion des particules d'aluminium sous pression, Thesis, Orléans University, France.

Melcher, J.C., Krier, H., and Burton, R.L. (2000), Combustion of aluminum in solid rocket motors flows, Solid Propellant Chemistry, Combustion, and Motor Interior Ballistics, $V$. Yang, T.B. Brill, and W.Z. Ren, Vol. 185, Progress in Astronautics and Aeronautics, AIAA, Reston, VA, pp. 723-747.

Melcher, J.C, Krier, H., and Burton, R.L. (2002), Burning aluminum particles inside a laboratory-scale solid rocket motor, J. Prop. Power, 18:3, 631.

Mellor, A.M., and Glassman, I. (1964), Vapor phase diffusion flames in the combustion of magnesium and aluminum: III. Experimental observations in carbon dioxide atmospheres, Heterogeneous combustion, Progress in Astronautics and Aeronautics, H.G. Wolfhard, I. Glassman, and L. Green Jr., Academic Press, New-York and London, Vol. 15, pp. 41-73. 
Merzhanov, A.G., Grigorjev, Y.M., and Gal'chenko, Y.A. (1977), Aluminium ignition, Combust. Flame, 29, 1.

Olsen, S.E., and Beckstead, M.W. (1995), Burn time measurements of single aluminum particles in steam and carbon dioxide, $31^{\text {st }}$ AIAA/ASME/SAE/ASEE Joint propulsion conference and exhibit, San Diego, AIAA paper 95-2715.

Prentice, J.L. (1970), Combustion of pulse-heated single particles of aluminum and beryllium, Combust. Science and Technology, 1, 385.

Prentice, J.L. (1974), Aluminum droplet combustion: rates and mechanisms in wet and dry oxidizers, Naval Weapons Center, China lake, California, Technical Report 5569.

Price, E.W. (1984), Fundamentals of solid propellant combustion, Progress in Astronautics and Aeronautics, Vol. 90, Chap. 9, pp. 479-513.

Qiu, C., and Metselaar, R. (1997), Phase relations in the aluminium carbide-aluminum nitridealuminum oxide system, J. Am. Ceramic Soc., 80:8, 2013.

Ranz, W.E., and Marshall, W.R. (1952), Evaporation from drops, Part I and II, Chemical Engineering Progress, 48:3, 141\&173.

Rossi, S., Drezin, E.L., and Law, C.K. (2001), Combustion of aluminum particles in carbon dioxide, Combust. Science and Technology, 164, 209.

Sarou-Kanian, V. (2003), Etude expérimentale de la combustion de gouttes d'aluminium en convection force: Influence de l'atmosphère gazeuse, Thesis, Orléans University, France.

Sarou-Kanian, V., Millot, F., and Rifflet, J.C. (2003), Surface tension and density of oxygenfree liquid aluminum at high temperature, Int. J. of Thermophysics, 24:1, 277.

Sarou-Kanian, V., Rifflet, J.C., Millot, F., Matzen, G., and Gökalp, I. (2004), Influence of nitrogen in aluminum droplet combustion, Proc. Combust. Inst., 30:2, 2060. 
Servaites, J., Krier, H., Melcher, J.C., and Burton, R.L. (2001), Ignition and combustion of aluminum particles in shocked $\mathrm{H}_{2} \mathrm{O} / \mathrm{O}_{2} / \mathrm{Ar}$ and $\mathrm{CO}_{2} / \mathrm{O}_{2} / \mathrm{Ar}$ mixtures, Combust. Flame, 125 , 1040.

Talbot, D.E.J. (1975), Effects of hydrogen in aluminium, magnesium, copper, and their alloys, Int. Metal. Rev., 20, 166.

Turns, S.R., and Wong, S.C. (1990), Combustion of aluminum-based slurries, Encyclopedia of environmental control technology, Vol. 4, Hazardous waste containment and treatment, pp. 641-683.

Widener, J.F., and Beckstead, M.W. (1998), Aluminum combustion modelling in solid propellant combustion products, $34^{\text {th }}$ AIAA/ASME/SAE/ASEE Joint propulsion conference and exhibit, Cleveland, AIAA paper 98-3824.

Wille, G., Rifflet, J.C., and Millot, F. (2002), Physico-chemical properties op liquid iron, Int. J. of Thermophysics, 23, 1197.

Wilson, R.P., and Williams, F.A. (1971), Experimental study of the combustion of single aluminium particles in $\mathrm{O}_{2} / \mathrm{Ar}$, Proc. Combust. Instit., 13, 833.

Yuasa, S., Sogo, S., and Isoda, H. (1992), Ignition and combustion of aluminum in carbon dioxide streams, Proc. Comb. Instit, 24, 1817.

Wiskel, J.B., Henein, H., and Maire, E. (2002), Solidification study of aluminum alloys using impulse atomization: Part I: Heat transfer analysis of an atomized droplet, Canadian Metallurgical Quarterly, 41:1, 97.

Zenin, A., Kusnezov, G., and Kolesnikov, V. (1999), Physics of aluminum particle combustion at zero-gravity, $37^{\text {th }}$ AIAA Aerospace Sciences Meeting and Exhibit, Reno, AIAA99-0696. 
Zenin, A., Kusnezov, G., and Kolesnikov, V. (2000), Physics of aluminum particle combustion at convection, $38^{\text {th }}$ AIAA Aerospace Sciences Meeting and Exhibit, Reno, AIAA2000-0849.

Zenin, A., Kusnezov, G., and Kolesnikov, V. (2001), Physics of aluminum particle combustion at ultrasonic levitation, $39^{\text {th }}$ AIAA Aerospace Sciences Meeting and Exhibit, Reno, AIAA-2001-0472. 


\section{TABLES}

Table I : Mean experimental parameters (droplet temperature, burning rate, oxide cap rate, exponent $n$, Reynolds, Nusselt and Sherwood numbers, stagnant burning rate) obtained in $\mathrm{CO}_{2}$ containing mixtures and pure $\mathrm{H}_{2} \mathrm{O}$.

\begin{tabular}{|c|c|c|c|c|c|c|c|c|}
\hline Atmosphere & $\begin{array}{c}T_{\text {droplet }} \\
(K)\end{array}$ & $\begin{array}{c}\beta \\
\left(\mathrm{mm}^{2} / \mathrm{s}\right)\end{array}$ & $\begin{array}{c}K \\
\left(\mathrm{~mm}^{2} / \mathrm{s}\right)\end{array}$ & $\operatorname{Exp} . n$ & $\operatorname{Re}$ & $N u$ & $S h$ & $\begin{array}{c}\beta_{\text {stag }} \\
\left(\mathrm{mm}^{2} / \mathrm{s}\right)\end{array}$ \\
\hline $100 \% \mathrm{H}_{2} \mathrm{O}$ & $2550 \pm 50$ & 3.02 & 0.39 & $2.05 \pm 0.05$ & 480 & 13.8 & 13.1 & 0.45 \\
\hline $80 \% \mathrm{H}_{2} \mathrm{O} / 20 \% \mathrm{CO}_{2}$ & $2570 \pm 50$ & 2.45 & 0.34 & $1.70 \pm 0.05$ & 600 & 16.1 & 14.7 & 0.33 \\
\hline $50 \% \mathrm{H}_{2} \mathrm{O} / 50 \% \mathrm{CO}_{2}$ & $2620 \pm 50$ & 1.70 & 0.35 & $1.15 \pm 0.05$ & 735 & 18.0 & 16.3 & 0.20 \\
\hline $20 \% \mathrm{H}_{2} \mathrm{O} / 80 \% \mathrm{CO}_{2}$ & $2600 \pm 50$ & 1.38 & 0.32 & $0.72 \pm 0.05$ & 890 & 19.2 & 18.0 & 0.15 \\
\hline $12.5 \% \mathrm{H}_{2} \mathrm{O} / 87.5 \% \mathrm{CO}_{2}$ & $2600 \pm 50$ & 1.32 & 0.43 & N.C. & N.C. & N.C. & N.C. & N.C. \\
\hline Wet $\mathrm{CO}_{2}{ }^{*}$ & $2600 \pm 50$ & 1.28 & 0.38 & $0.58 \pm 0.13$ & 1000 & 18.1 & 19.1 & 0.14 \\
\hline $50 \% \mathrm{H}_{2} \mathrm{O} / 25 \% \mathrm{CO}_{2} / 25 \% \mathrm{~N}_{2}$ & $2450 \pm 50$ & 1.41 & 0.18 & $1.45 \pm 0.07$ & N.C. & N.C. & N.C. & N.C. \\
\hline $20 \% \mathrm{H}_{2} \mathrm{O} / 40 \% \mathrm{CO}_{2} / 40 \% \mathrm{~N}_{2}$ & $2450 \pm 50$ & 0.92 & 0.19 & $0.70 \pm 0.05$ & N.C. & N.C. & N.C. & N.C. \\
\hline Wet $50 \% \mathrm{CO}_{2} / 50 \% \mathrm{~N}_{2}{ }^{*}$ & $2500 \pm 50^{* *}$ & 0.58 & 0.14 & N.C. & 860 & 16.5 & 18.1 & 0.07 \\
\hline
\end{tabular}


Table II : Mass and molar fraction of carbon in unburnt residues in several $\mathrm{CO}_{2}$ containing atmospheres.

\begin{tabular}{cccc}
\hline Atmosphere & $\begin{array}{c}\text { Experimental mass } \\
\text { fraction of carbon }(\%)\end{array}$ & $\begin{array}{c}\text { Calculated molar fraction } \\
\text { of carbon }(\%)\end{array}$ & Burning time $(s)$ \\
\hline $80 \% \mathrm{H}_{2} \mathrm{O} / 20 \% \mathrm{CO}_{2}$ & $3.5 \pm 0.3$ & $7.3 \pm 0.3$ & 3.5 \\
$80 \% \mathrm{H}_{2} \mathrm{O} / 20 \% \mathrm{CO}_{2}$ & $4.7 \pm 0.3$ & $9.1 \pm 0.3$ & 2.9 \\
$20 \% \mathrm{H}_{2} \mathrm{O} / 40 \% \mathrm{CO}_{2} / 40 \% \mathrm{~N}_{2}$ & $10.8 \pm 1.0$ & $20.0 \pm 2.0$ & 10 \\
$50 \% \mathrm{H}_{2} \mathrm{O} / 50 \% \mathrm{CO}_{2}$ & $9.9 \pm 0.7$ & $19.5 \pm 1.0$ & 5.1 \\
$\mathrm{Wet} 50 \% \mathrm{CO}_{2} / 50 \% \mathrm{~N}_{2}$ & $11.5 \pm 0.6$ & $21.5 \pm 1.0$ & 10 \\
$20 \% \mathrm{H}_{2} \mathrm{O} / 80 \% \mathrm{CO}_{2}$ & $12.7 \pm 0.2$ & $23.5 \pm 1.0$ & 6.5 \\
$\mathrm{Wet} \mathrm{CO}_{2}$ & $9.9 \pm 0.4$ & $19.5 \pm 1.0$ & 2.65 \\
\hline
\end{tabular}

" with the assumption of a mass fraction of oxygen: $0<\mathrm{Y}_{\mathrm{O}}<0.1$ 


\section{FIGURE CAPTIONS}

Figure 1: Ignition and combustion processes of an aluminum droplet in $80 \% \mathrm{H}_{2} \mathrm{O} / 20 \% \mathrm{CO}_{2}$.

Figure 2: Surface phenomena during the combustion of an aluminum droplet in $20 \% \mathrm{H}_{2} \mathrm{O} / 80 \% \mathrm{CO}_{2}$.

Figure 3: Thermal radiation profile of $\mathrm{Al}$ droplet burning in $\mathrm{CO}_{2}$ containing atmospheres.

Figure 4: Reduced squared diameter evolution as a function of reduced time for $\mathrm{CO}_{2}$ containing atmospheres and previous studied atmospheres (*, Sarou-Kanian et al., 2004).

Figure 5: Oxide cap size evolution for two burning droplets in wet $50 \% \mathrm{CO}_{2} / 50 \% \mathrm{~N}_{2}$ fitted by a " $\mathrm{d}^{n}$ law" with several values of $n$. The best fitting parameter corresponds to the smallest relative error $\Delta \mathrm{K} / \mathrm{K}$.

Figure 6: Global and detailed views of two unburnt residues in $50 \% \mathrm{H}_{2} \mathrm{O} / 50 \% \mathrm{CO}_{2}$.

Figure 7: Cross-sectioned unburnt residues in $50 \% \mathrm{H}_{2} \mathrm{O} / 50 \% \mathrm{CO}_{2} \quad(\mathrm{a}, \mathrm{b})$ and $20 \% \mathrm{H}_{2} \mathrm{O} / 80 \% \mathrm{CO}_{2}(\mathrm{c}, \mathrm{d})$.

Figure 8: Comparison of the calculated stagnant burning rates with the previous works with $\mathrm{CO}_{2}$ containing atmospheres.

Figure 9: Detail of a cross-sectioned unburnt residue in $20 \% \mathrm{H}_{2} \mathrm{O} / 80 \% \mathrm{CO}_{2}$ showing the ejection of the aluminum at the surface.

Figure 10: Detail of the Al-C phase diagram from Goksen and Oden (1998).

Figure 11: Aluminum vapor pressure ratio as a function of the molar fraction of dissolved carbon in liquid $\mathrm{Al}$ at $\mathrm{T}=2600 \mathrm{~K}$. 


\section{FIGURES}

Figure 1
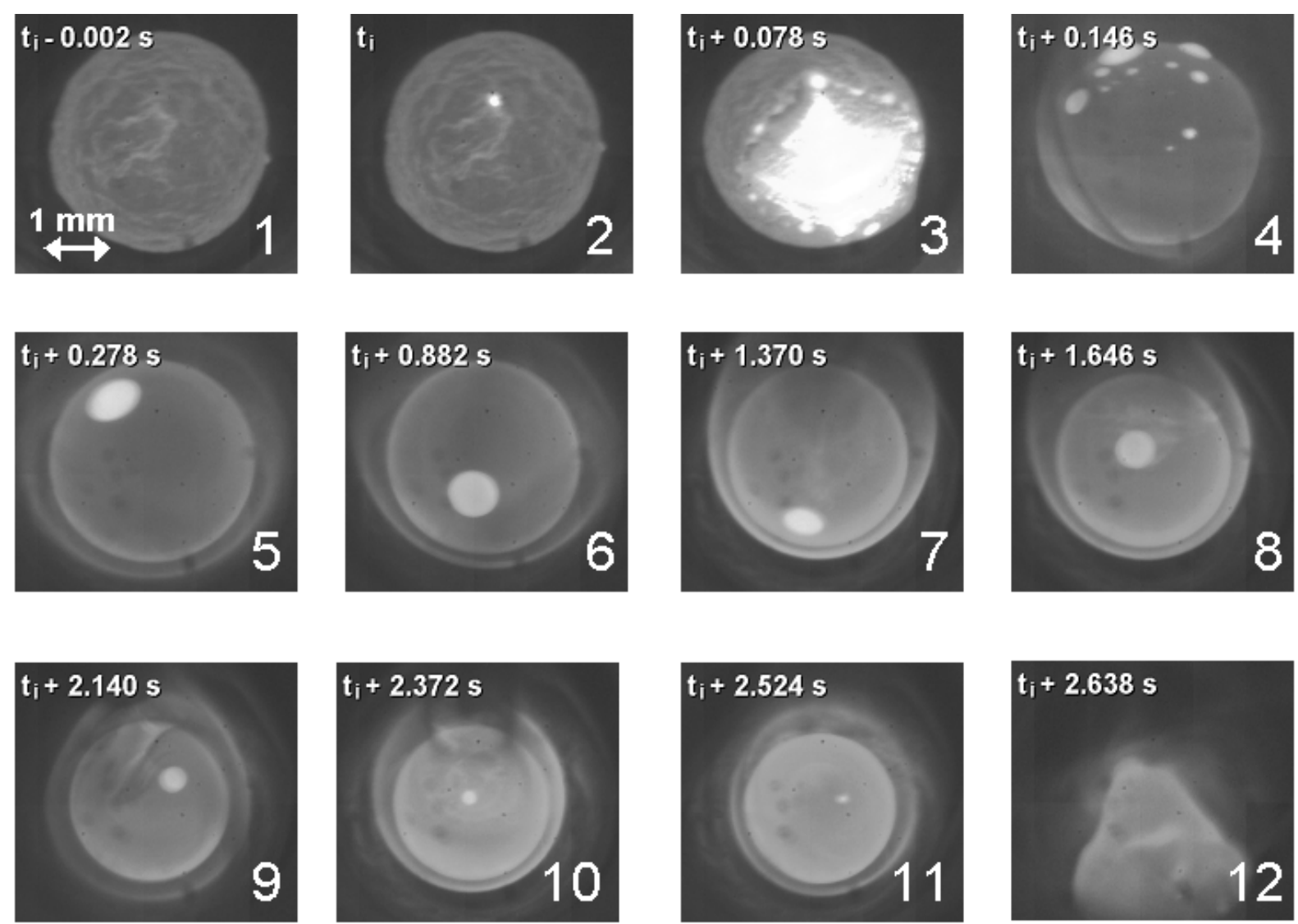
Figure 2
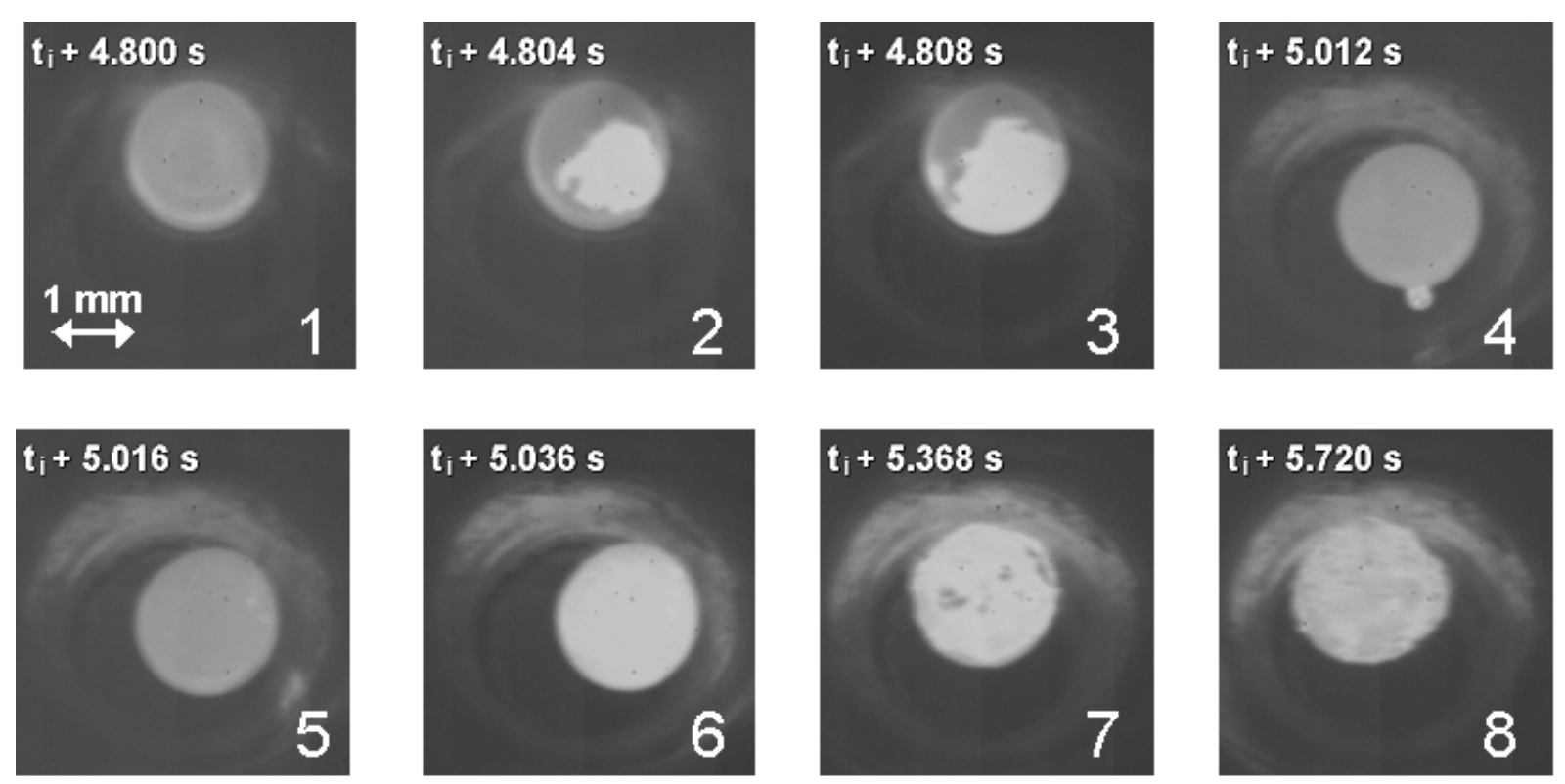
Figure 3
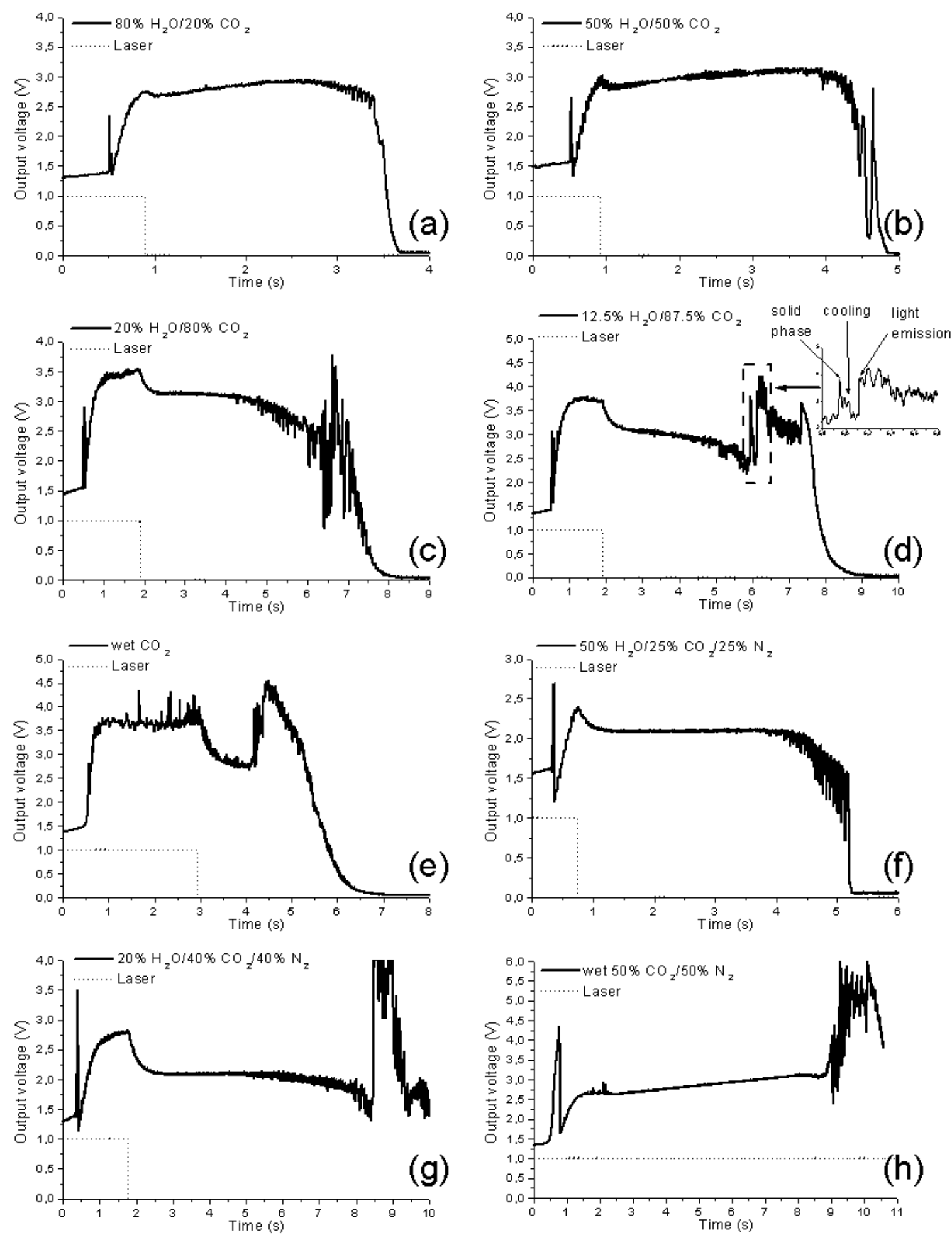
Figure 4
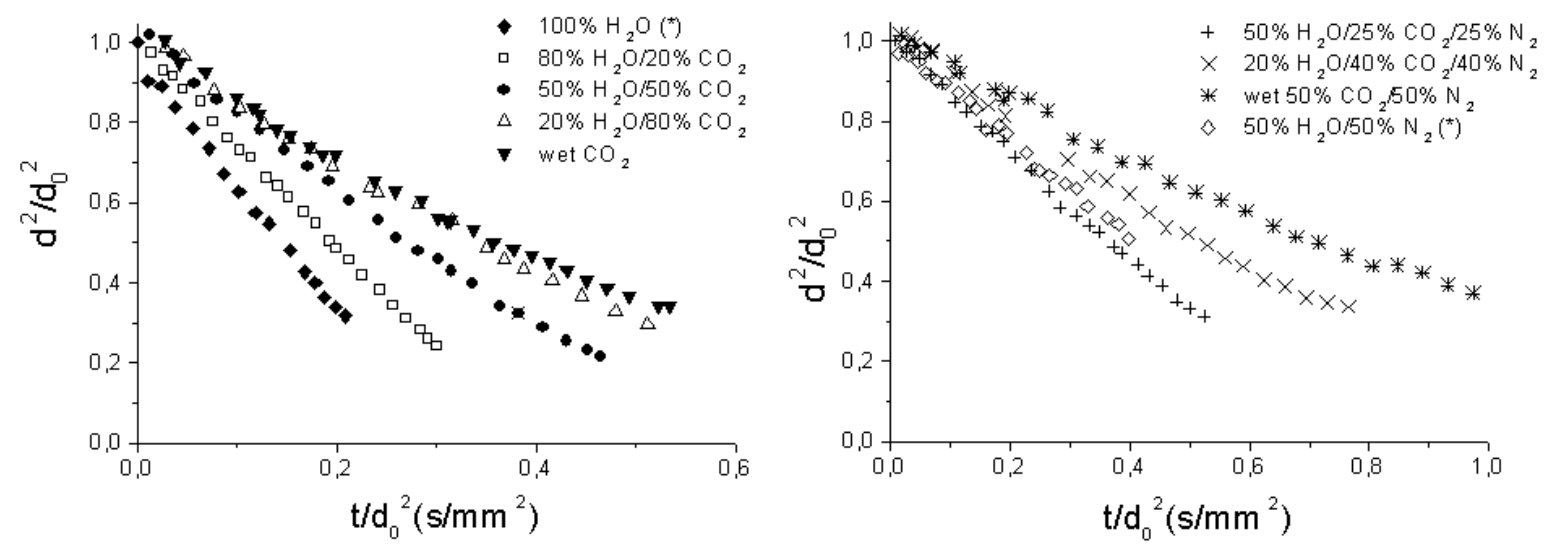
Figure 5

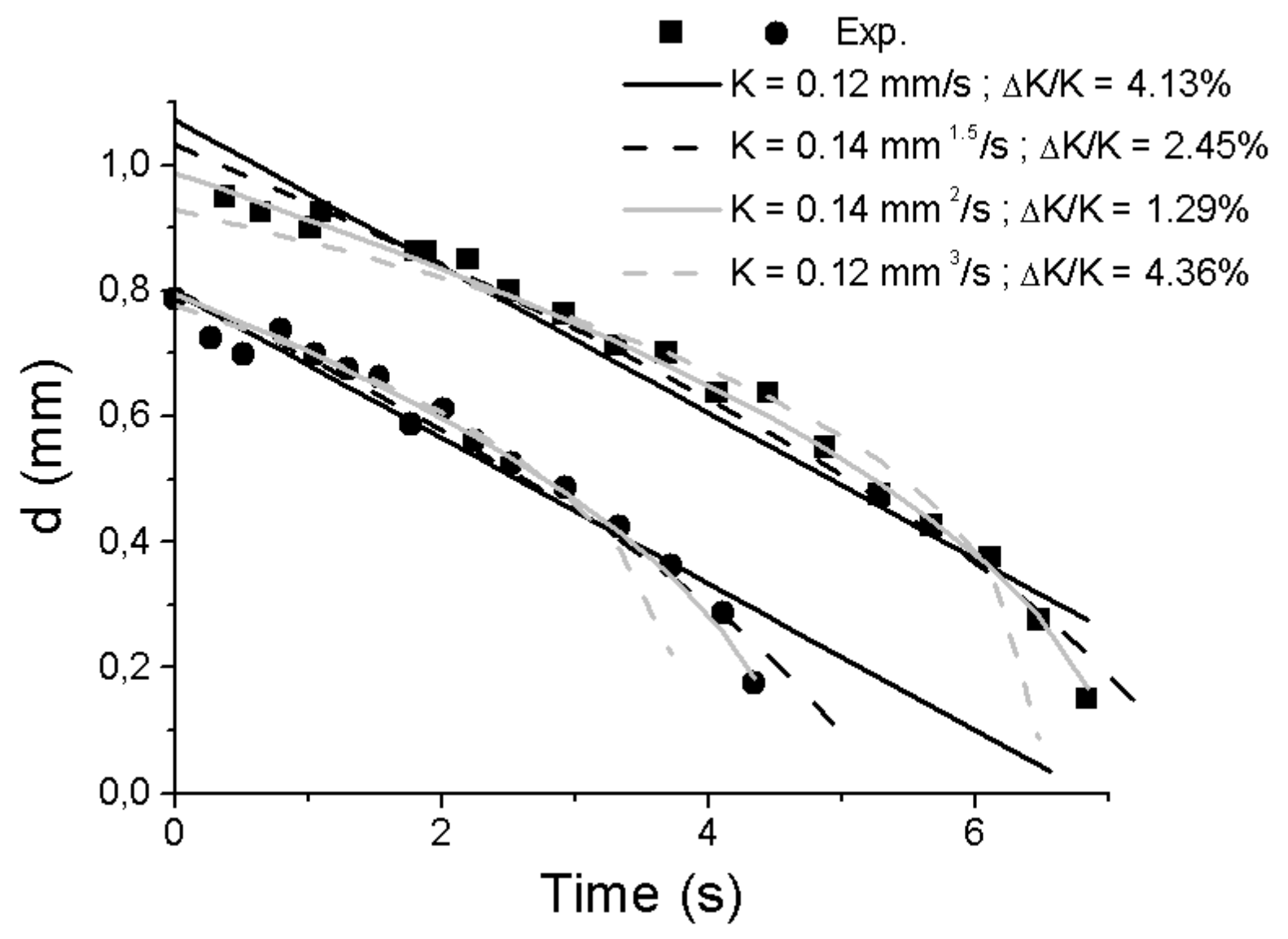


Figure 6
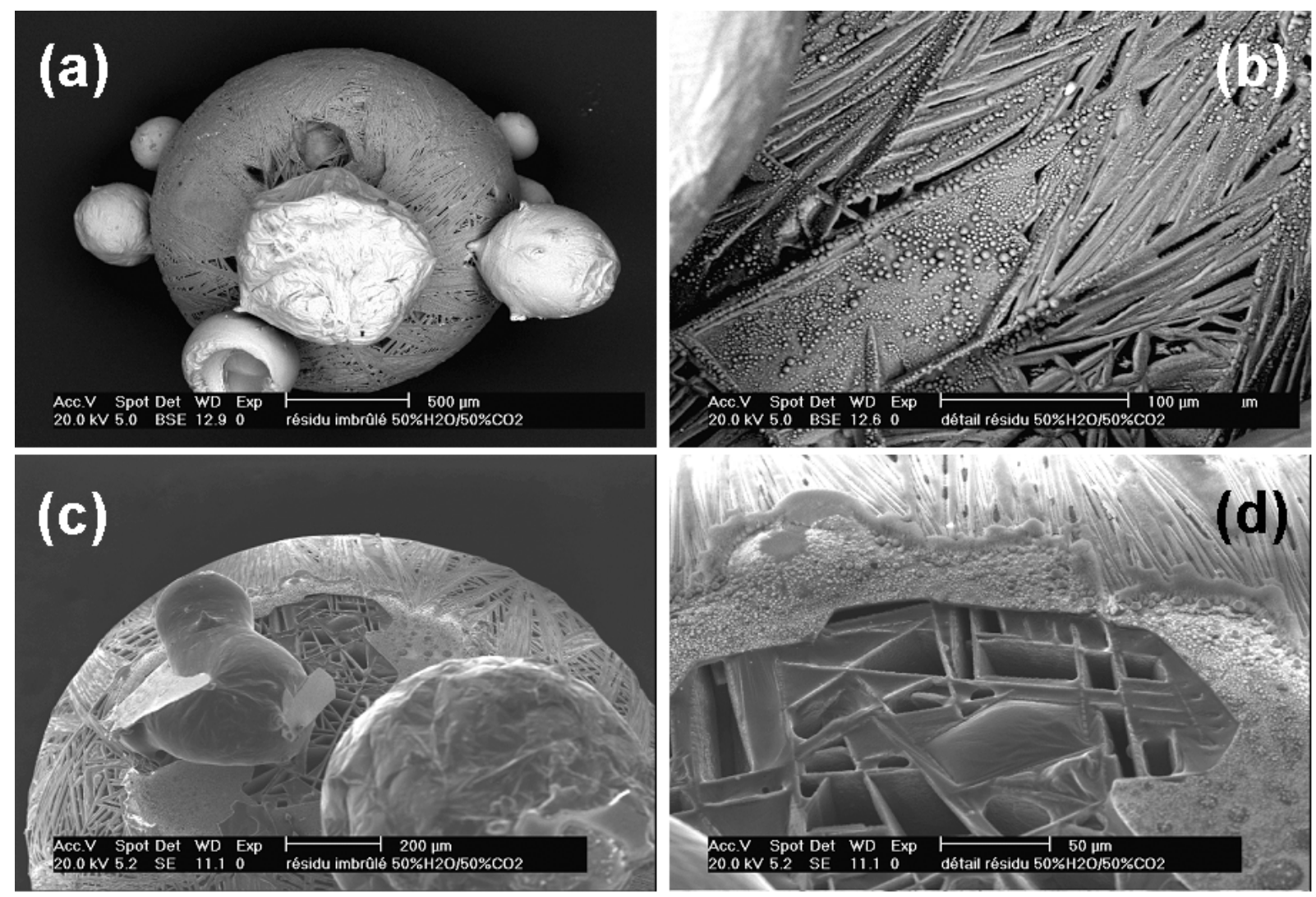
Figure 7
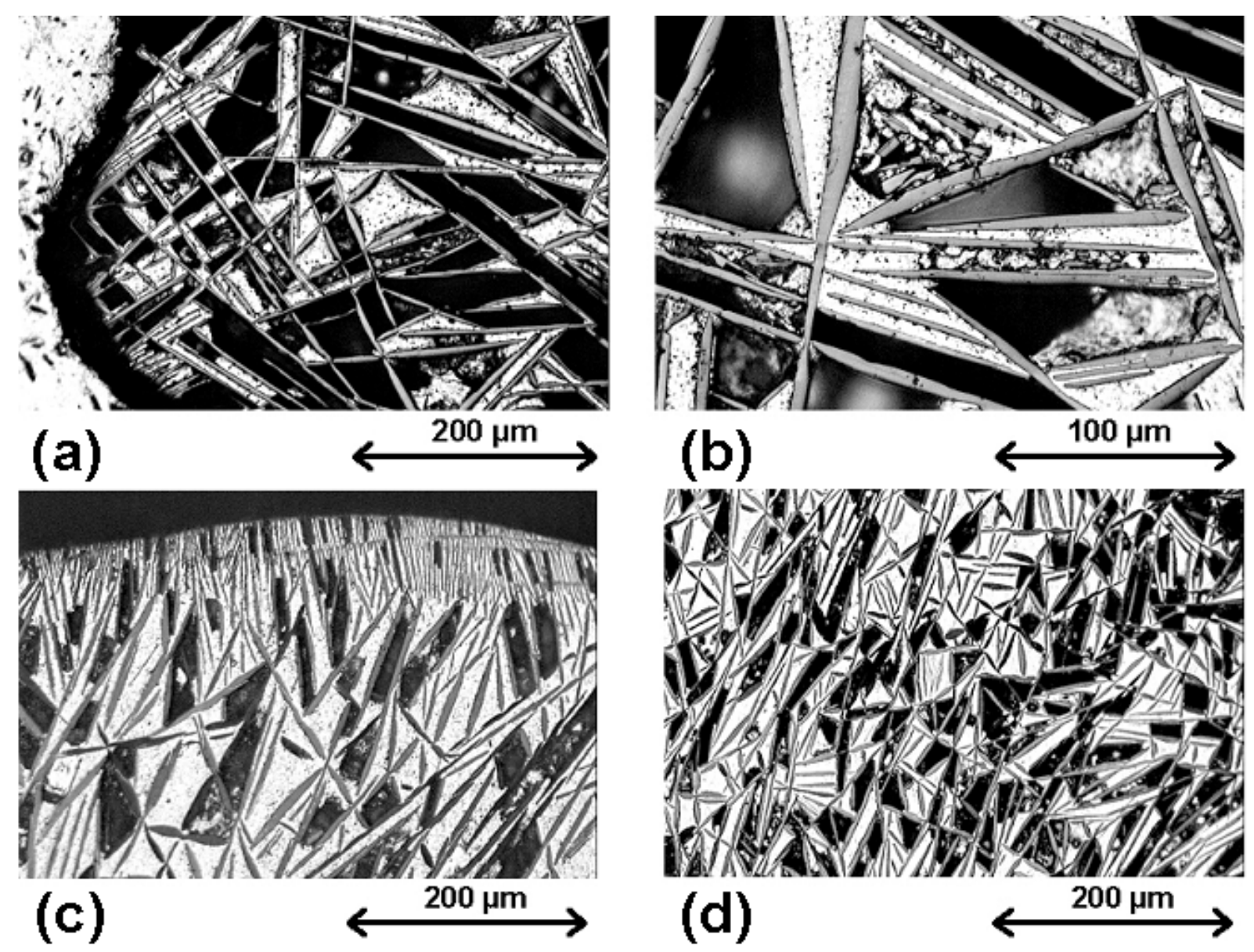
Figure 8

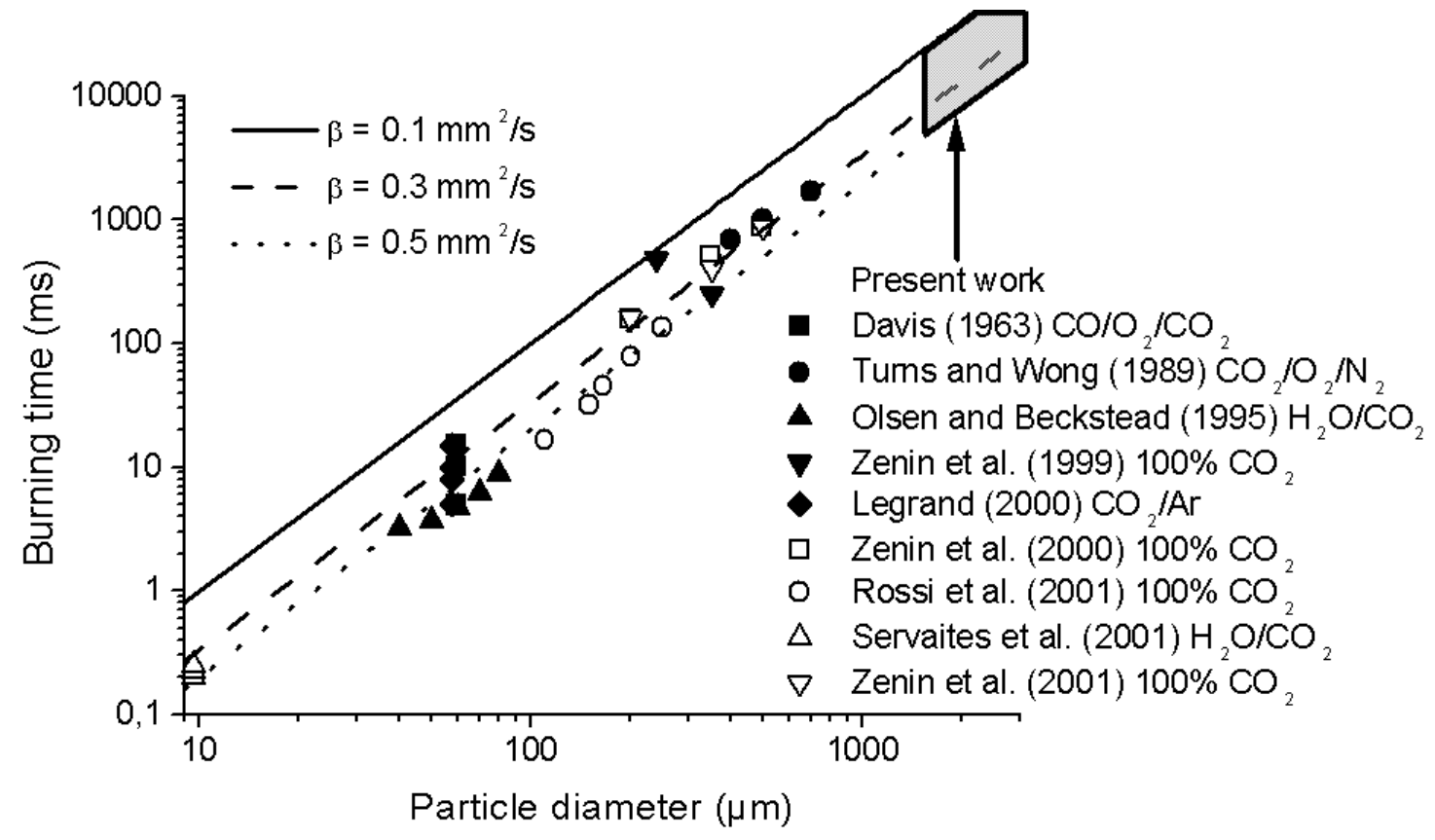


Figure 9

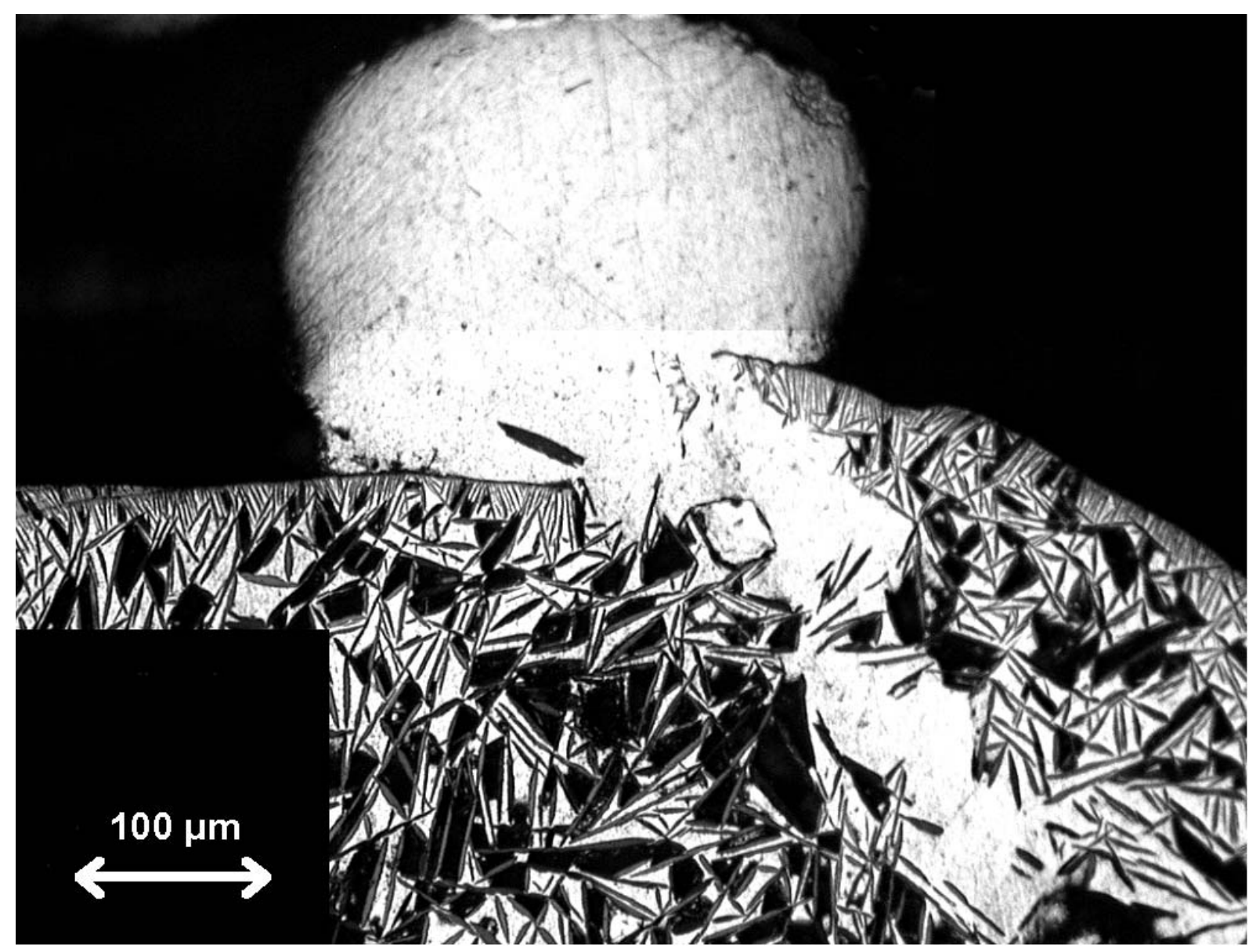


Figure 10

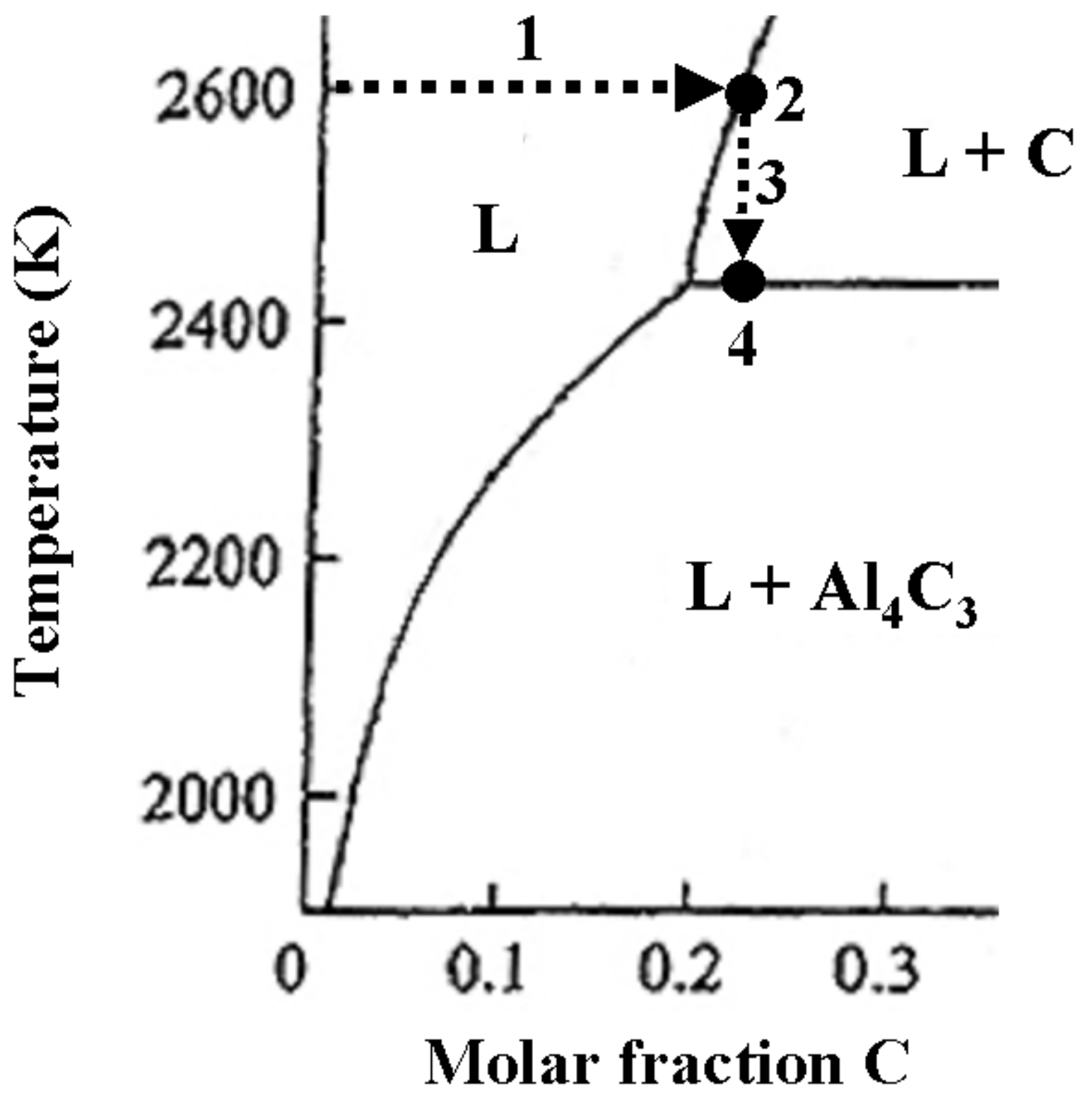


Figure 11

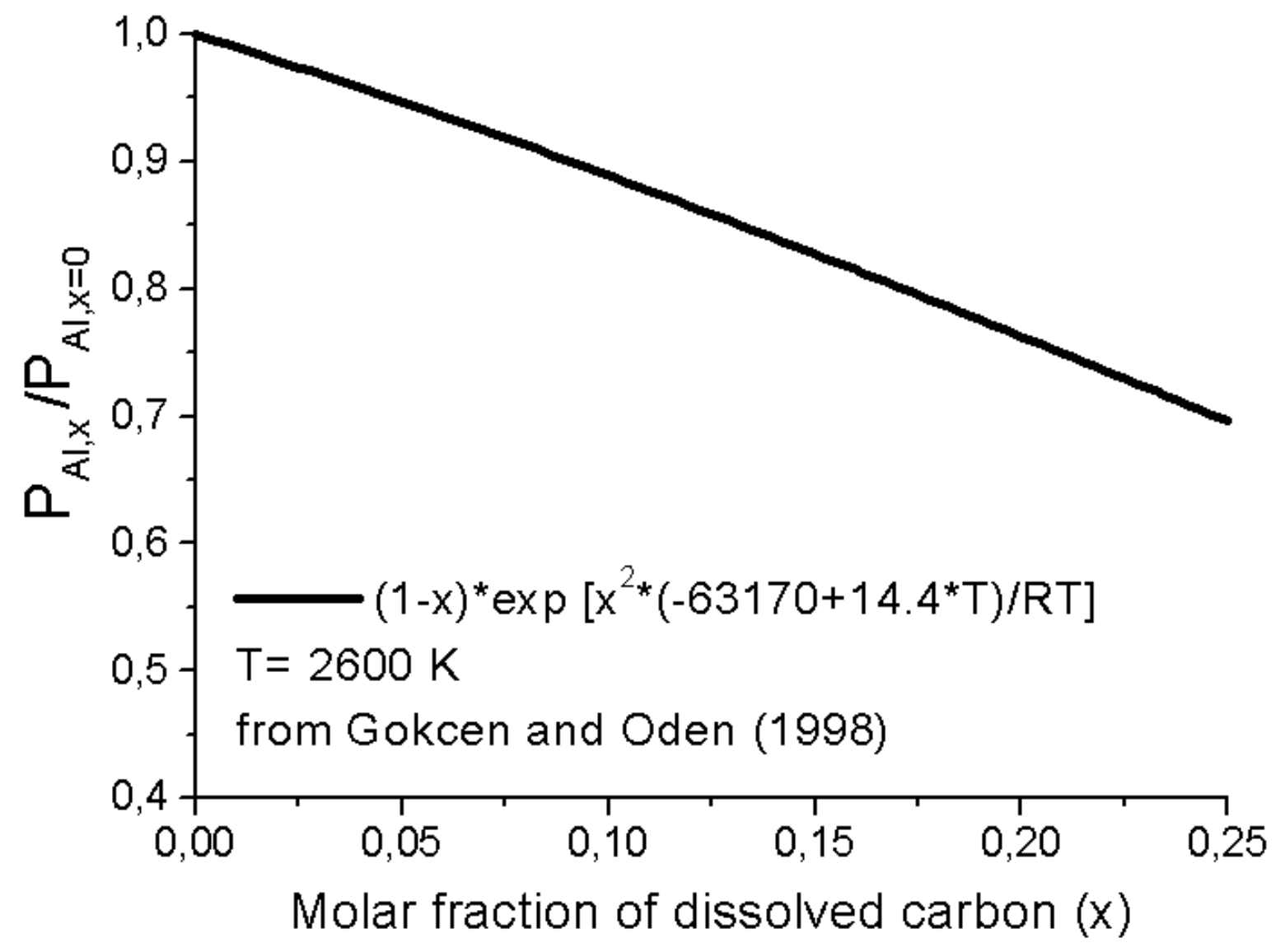

